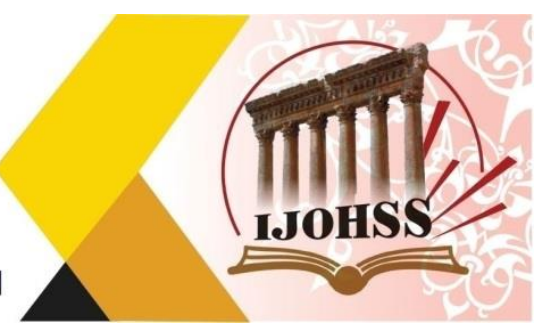

\title{
الصفة التبعية لالتزام الكفيل الشخصي في عقد الكفالة (دراسة تحليلية مقارنة)
}

\author{
م. حمودي بكر حمودي \\ قسم القانون- كلية الامام الأعظم (رحمة الله) الجامعة

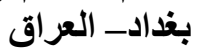

البريد الاكتروني: Hammoodi191979@gmail.com

الملخص

تعد الكفالة احدى صور التأمينات الثخصية التي تناولتها التشريعات ومنها القانون المدني العر اقي رقم 40 لسنة 1951 النافذ المعدل بنصوص خاصة لتنظيم احكامها، وفي بحثنا سلطنا الضوء على اهم مميزات عقد الكفالة و هي صفة تبعية التزام الكفيل لالتزام المدين الأصلي في وجوده وصحته ونطاقه وانقضائه من خلال تحليل

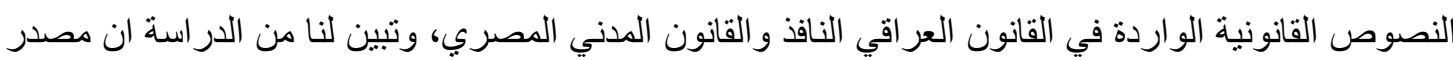
التزام الكفيل ومضمونه يختلف عن التزام المدين الأصلي الا ان وجود التزام الكفيل وصحته واوصافه تعتمد على

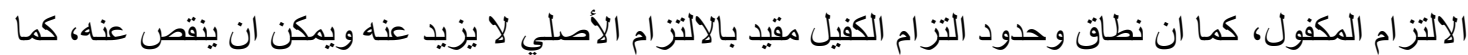
ان الدائن لا يستطيع الرجوع بدينه على الكفيل او ينفذ عليه قبل ان يرجع على المدين الأصلي، كذلك ان انقضاء

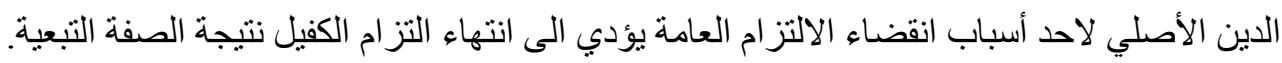




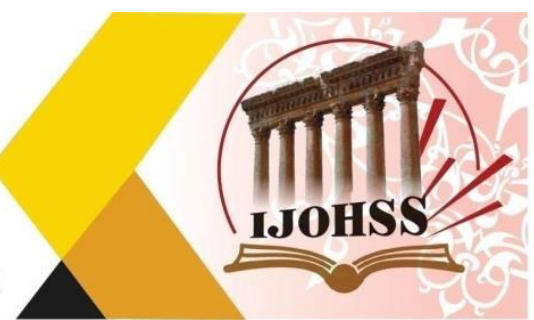

\title{
Subordination on to the Personal Guarantor Obligation in the Surety Contract (A comparative analytical study)
}

\author{
Lect. Hamodi Baker Hamodi \\ Al-Imam Al-Adhm University College - Law Department \\ Baghdad - Iraq \\ Email: Hammoodi191979@gmail.com
}

\begin{abstract}
The guarantee is one of the forms of personal insurance dealt with by legislation, including the Iraqi Civil Law No. 40 of 1951 in force, amended by special texts to regulate its provisions. The legal provisions contained in the Iraqi law in force and the Egyptian civil law, and it turns out to us from the study that the source and content of the guarantor's obligation differs from the original debtor's obligation, except that the existence of the guarantor's commitment, health and descriptions depend on the sponsored commitment, and the scope and limits of the guarantor's commitment are restricted to the original obligation not more than it and can be It is less than it, just as the creditor cannot recourse his debt to the guarantor or have it enforced against him before he returns to the original debtor. Also, the expiry of the original debt for one of the general reasons for the expiration of the obligation leads to the termination of the guarantor's obligation as a result of the dependent quality.
\end{abstract}

Keywords: dependency, guarantor, surety. 
ان اصحاب الحقوق الشخصية يستطيعون اللجو ء الى القانون للحصول على حقوقهم من خلال وسائل حماية

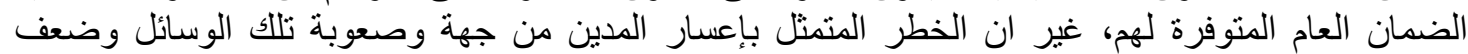

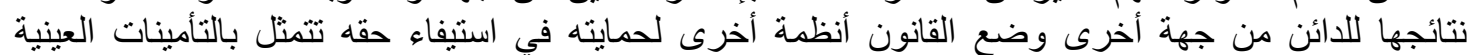

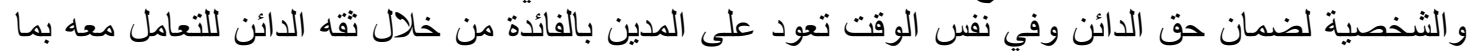

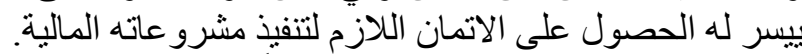

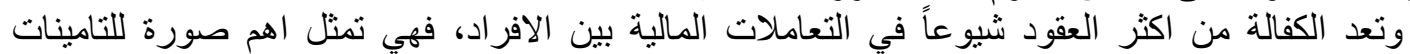

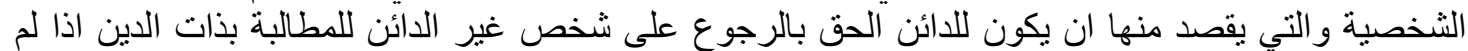

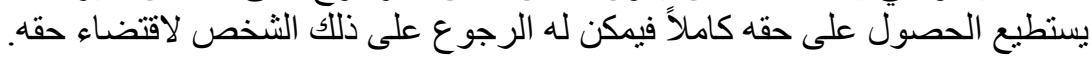

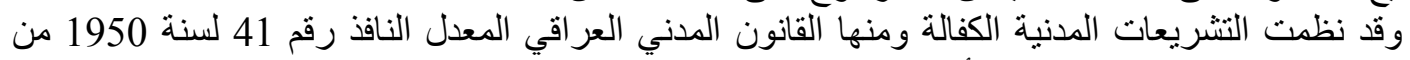

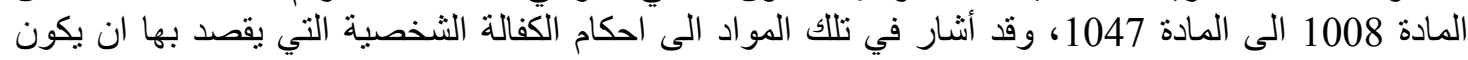

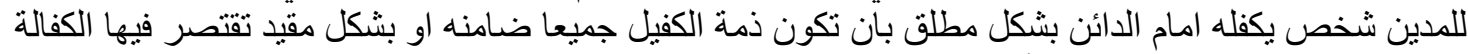

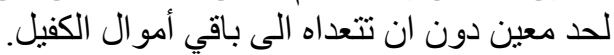

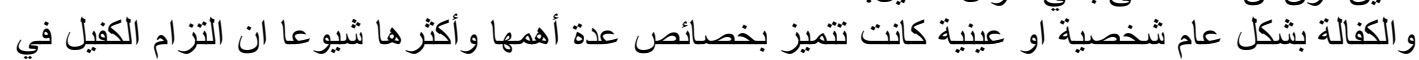

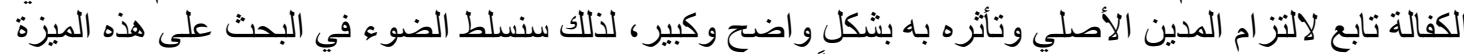

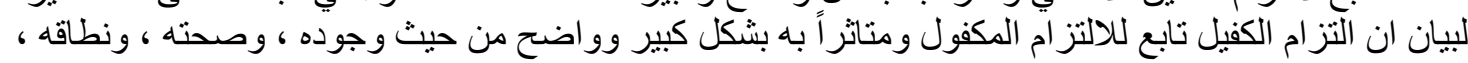

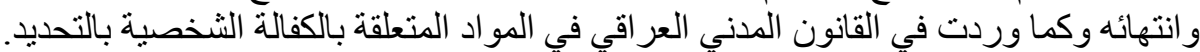

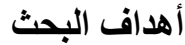

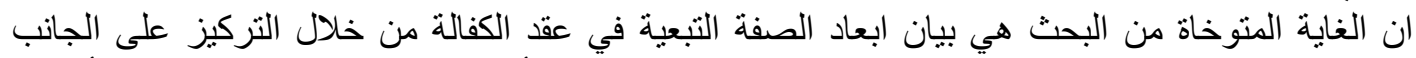

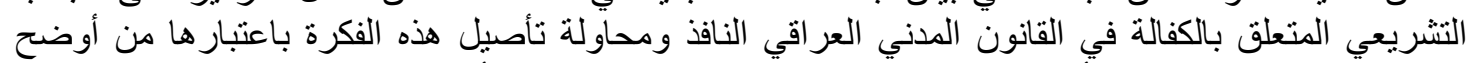

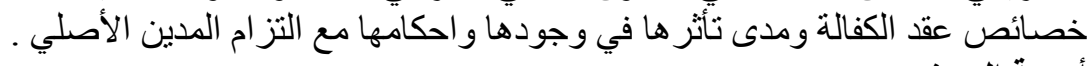

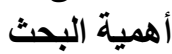

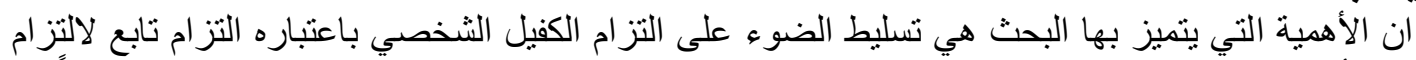

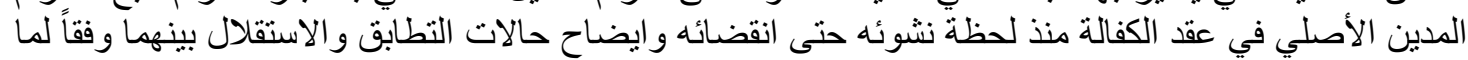

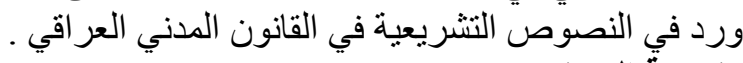

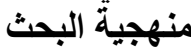

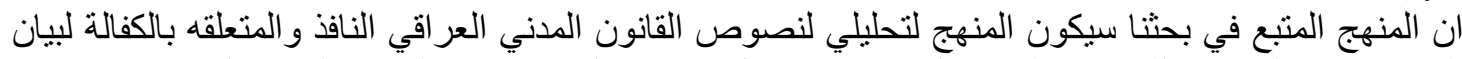

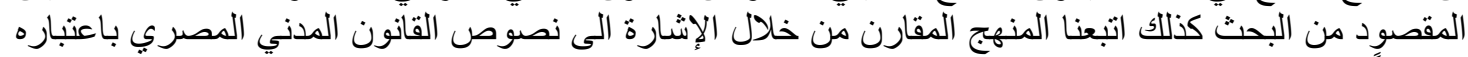

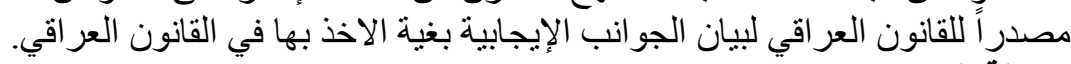

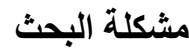

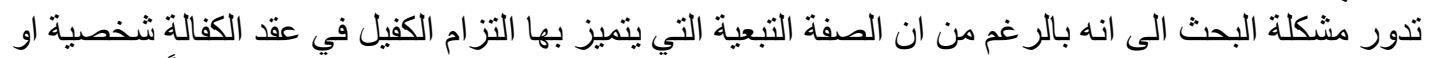

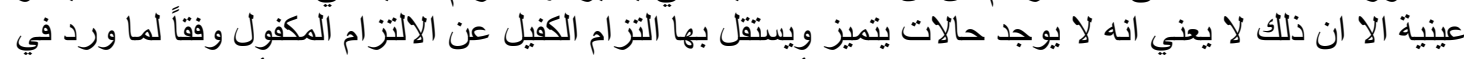

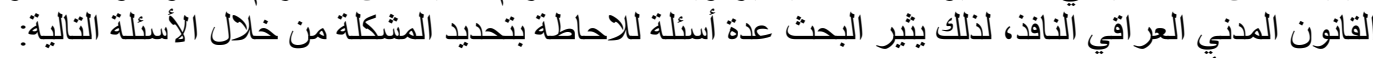

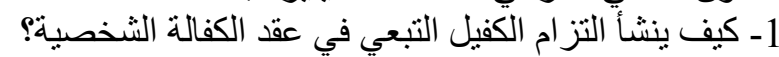

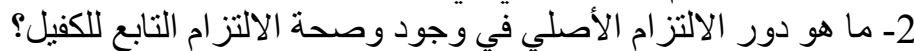

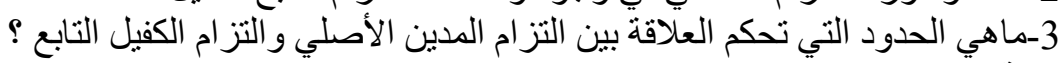

خطة البحث البث للإجابة على الأسئلة التي تطرحها مشكلة البحث يتطلب البحث تقسيمه الى التالي:

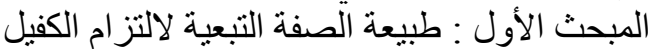

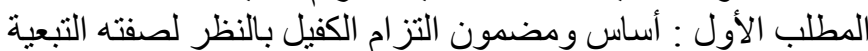

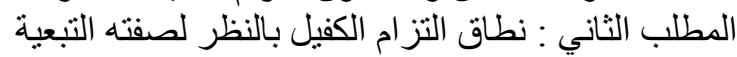

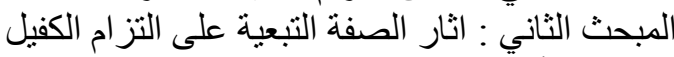
المطلب الأول : اثار الصفة التبعية على العلاقة بين الكئ الكفيل و الدائن 
المطلب الثاني: اثار الصفة التبعية على انقضاء التزام الكفيل

$$
\text { المبحث الأول }
$$

\section{طبيعة الصفة التبعية لالتزام الكفيل}

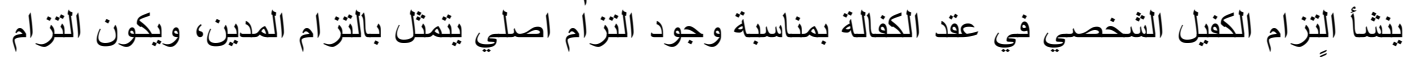

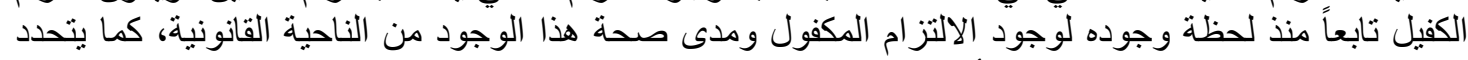

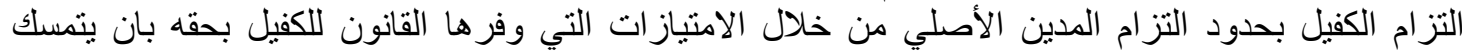

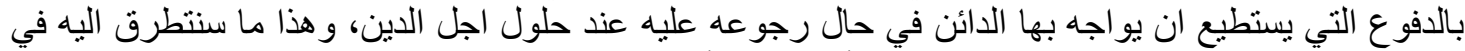

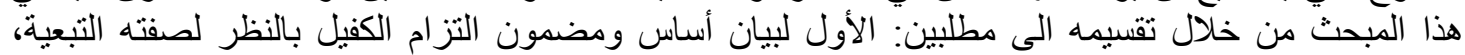

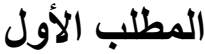
و الثاني مدى التز ام الكفيل بالنظر لصفته التبعية.

\section{أساس ومضمون التزام الكفيل بالنظر لصفته التبعية}

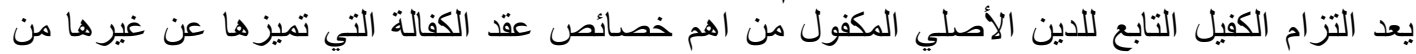

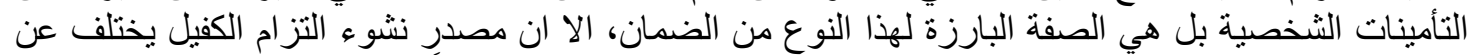

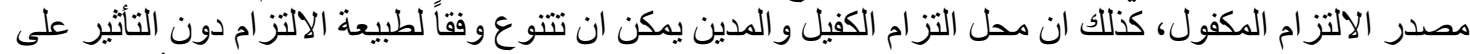

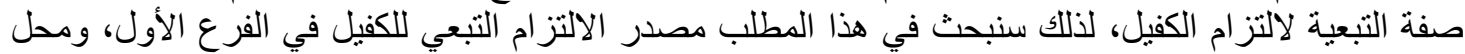

\section{الفرع الأول \\ مصدر الالتزام التبعي للكفيل}

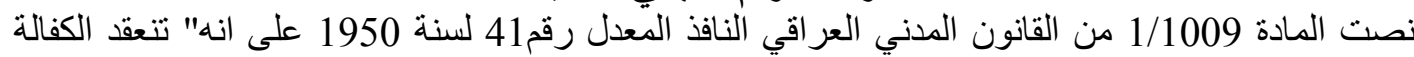

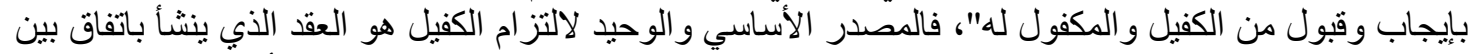

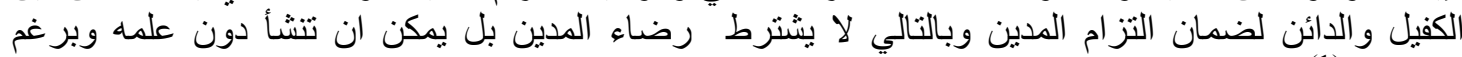

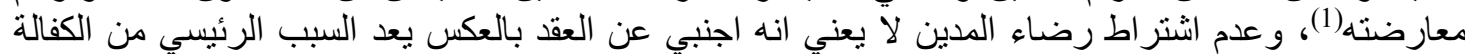

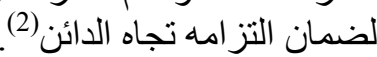

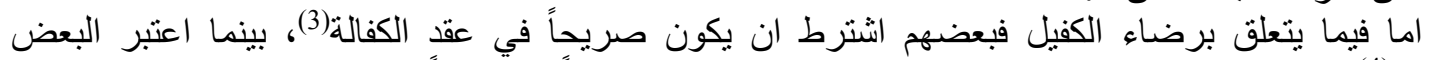

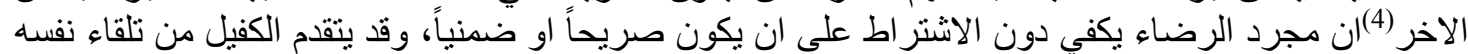

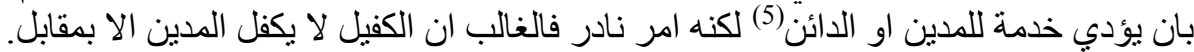

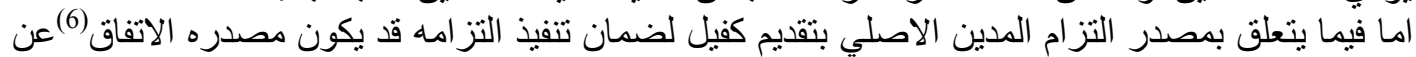

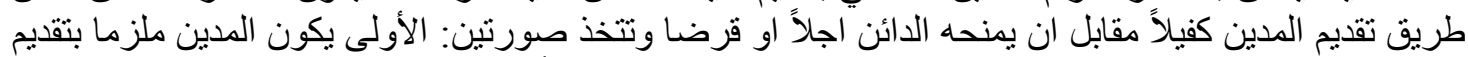

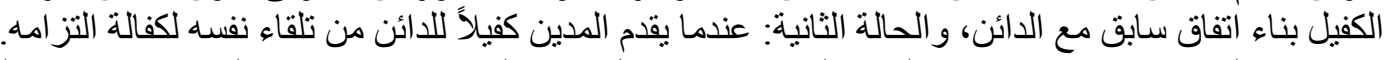

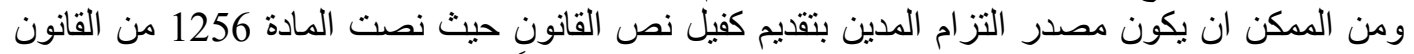

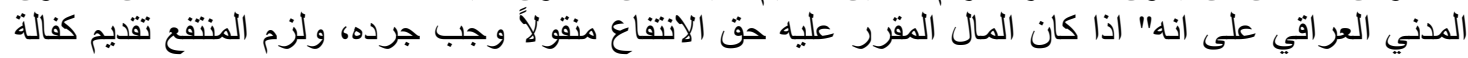

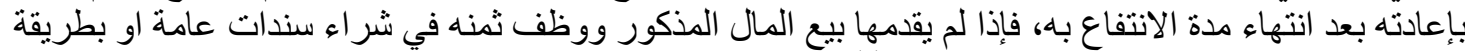

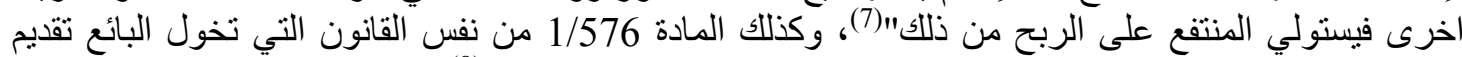

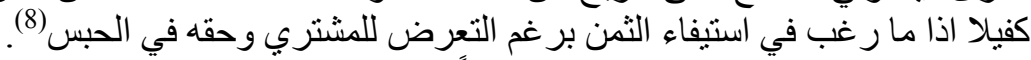

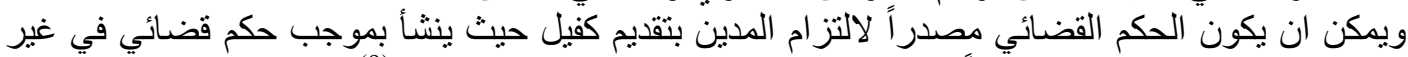

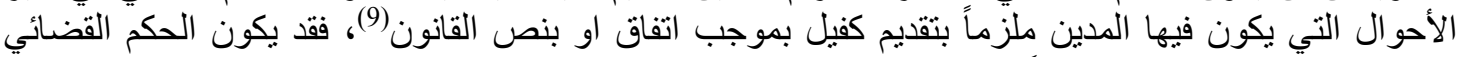

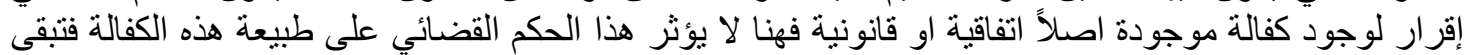

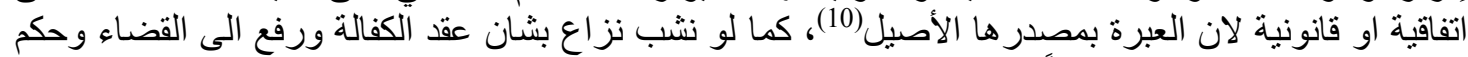

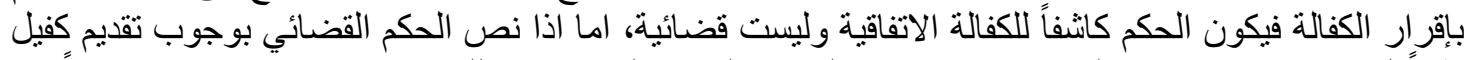

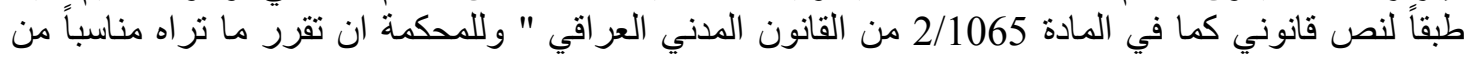




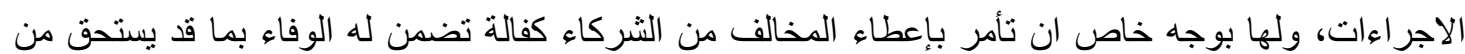

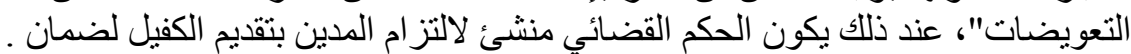

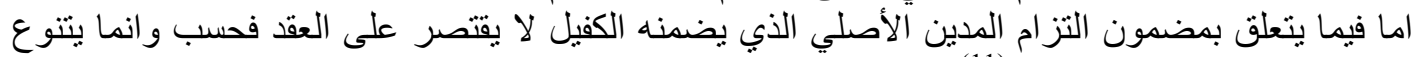

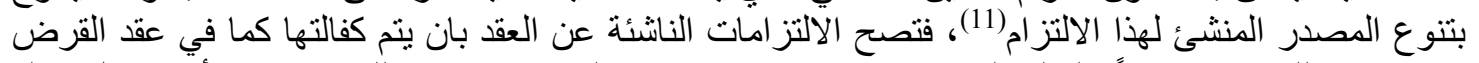

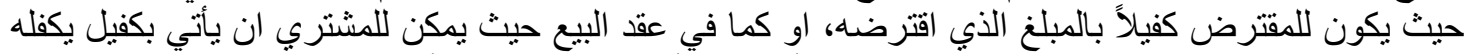

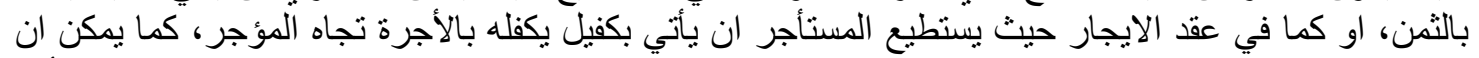

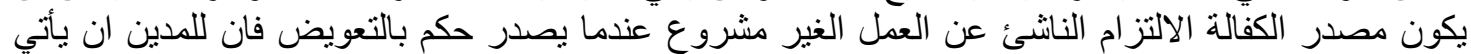

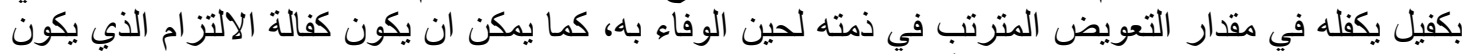

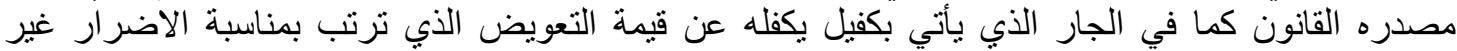

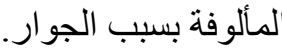
يتضح لنا مما تقدم ان التزام الكفيل ينشئ لضمان تنفيذ التزام المدين الأصلي (المكفول) ويختلف مصدر التهر

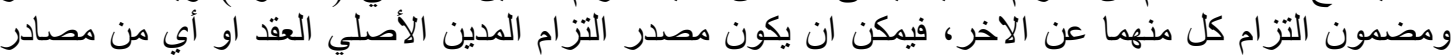

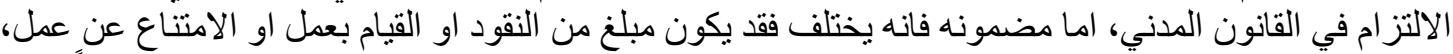

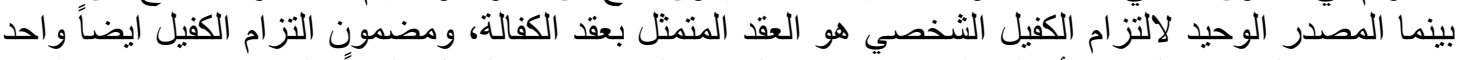

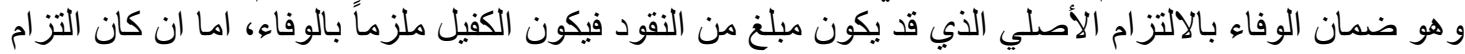

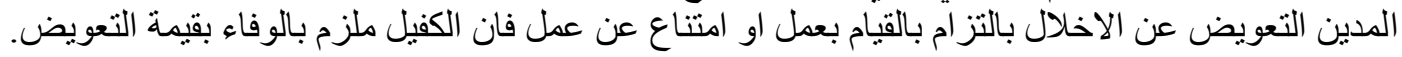

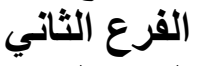 \\ محل الالتزام التبعي للكفيل التئي}

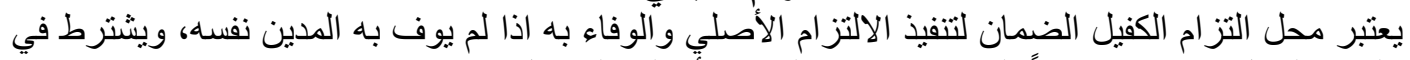

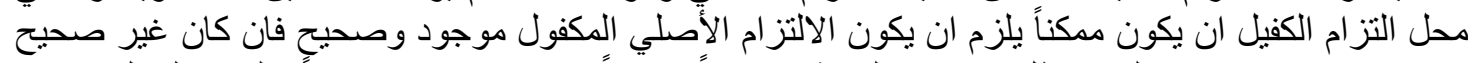

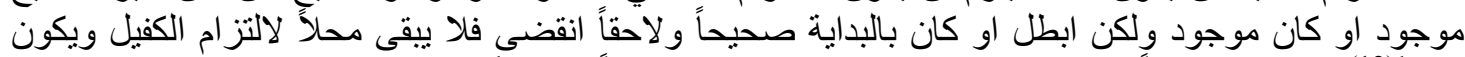

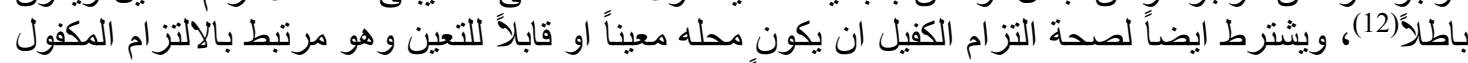

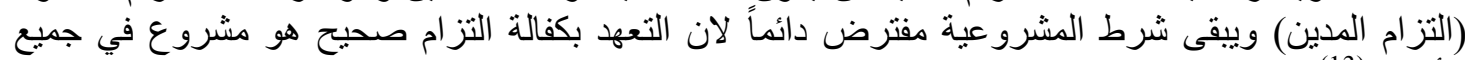

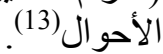

اولاً: وجود الالتزام الأصلي التي

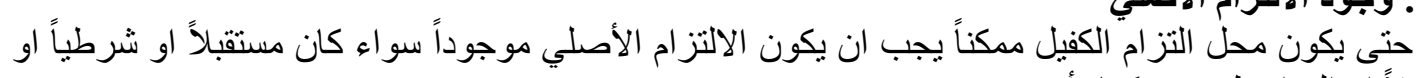

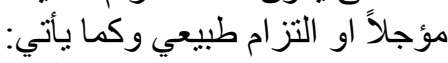

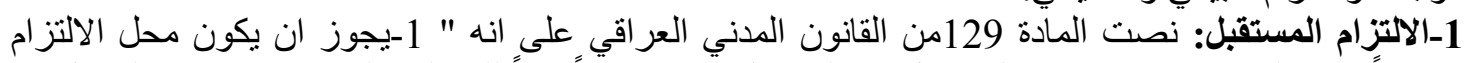

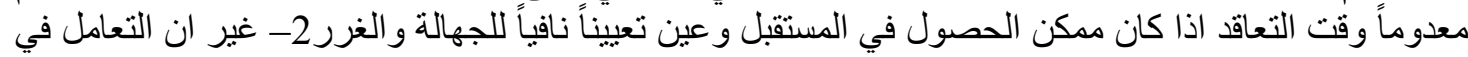

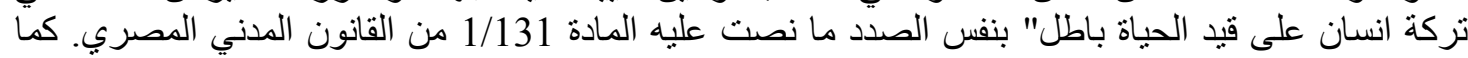

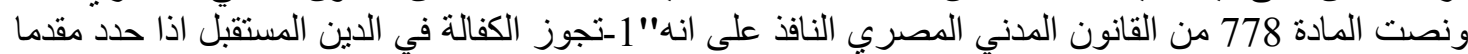

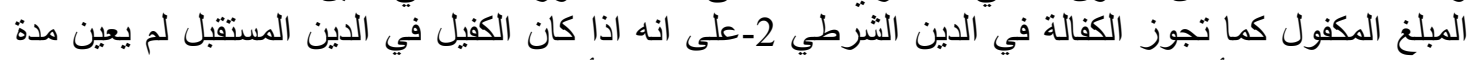

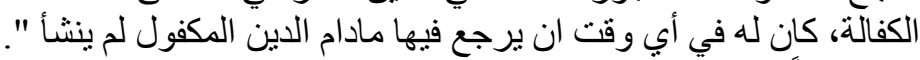

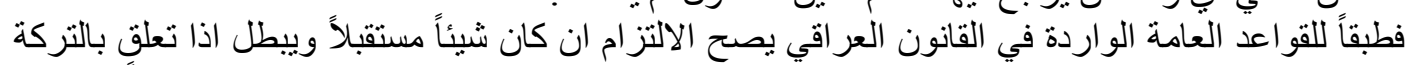

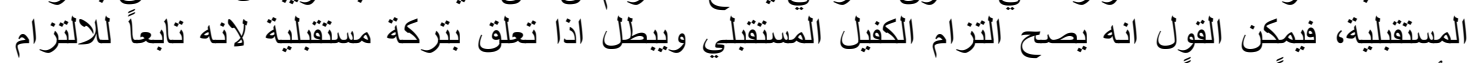

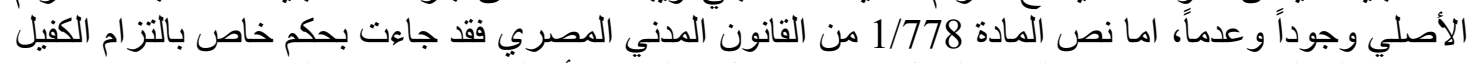

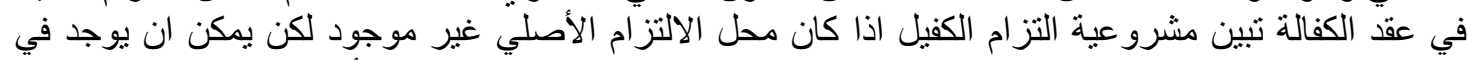

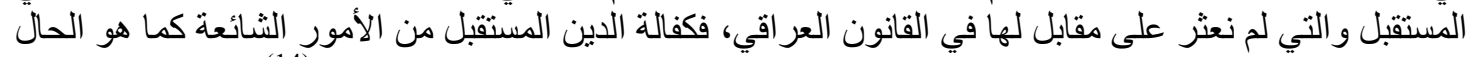

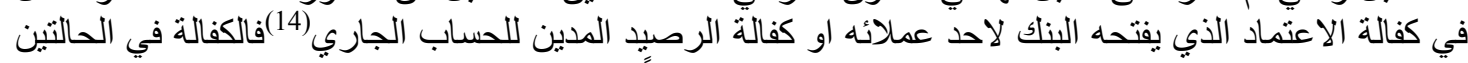

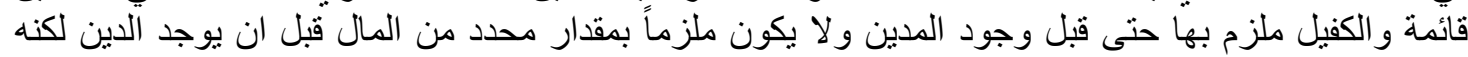

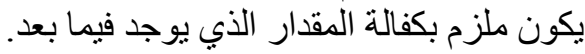

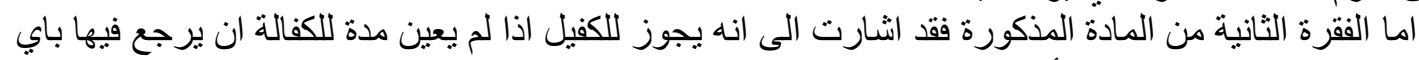

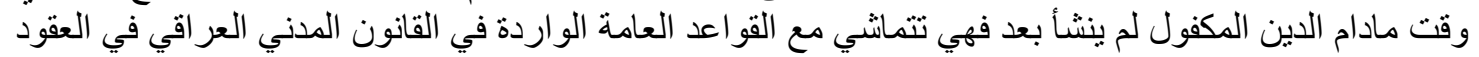




\section{المجلة اللحولية اللملوم الآنسانية والإمتماعية}

International Journal on Humanities and Social Sciences website:www.ijohss.com Email:editor@ijohss.com ISSN: 2415 - 4822

\section{العدد (23) أغسطس 2021 Volume (23) August 2021}

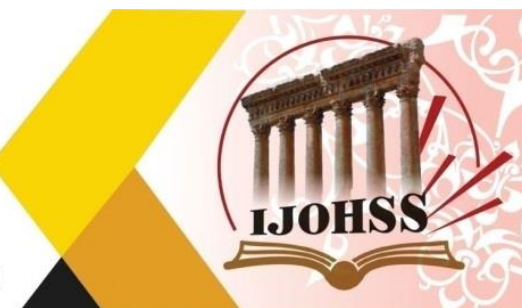

الغير محددة المدة(15)التي تجيز لاحد أطر افها ان ينهي العقد بار ادته المنفردة، ويعتبر الفقه(16) ان حق الكفيل

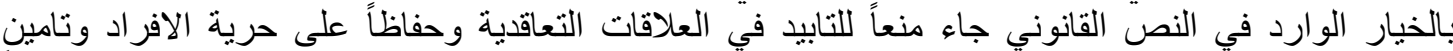

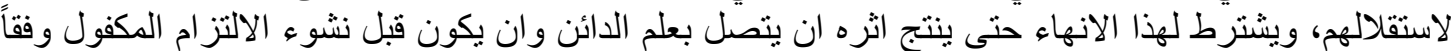

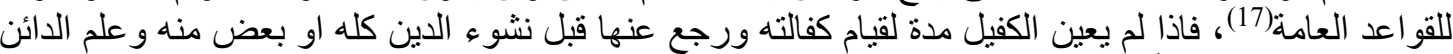

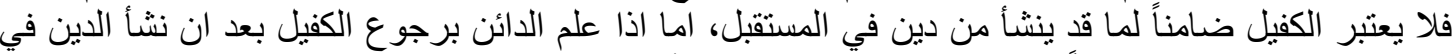

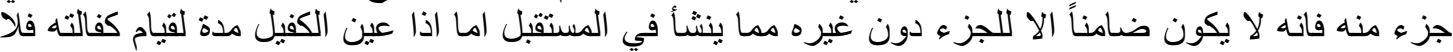

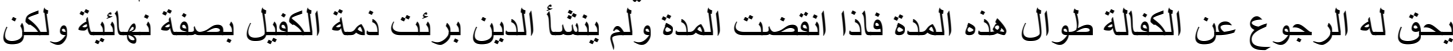

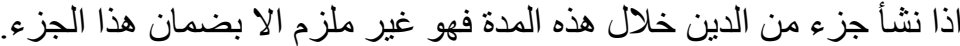

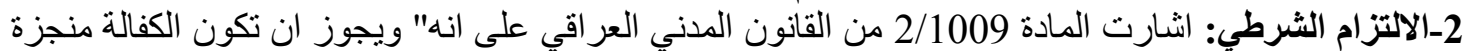

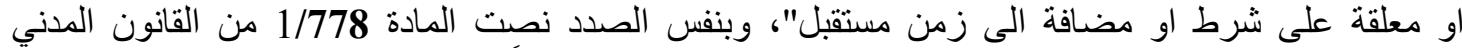
المصري النافذ على انه" تجوز الكفالة في الدين المستقبل إذا حدد مقدماً المبلغ المكفول، كما تجوز الكفالة في الي الئي

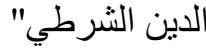

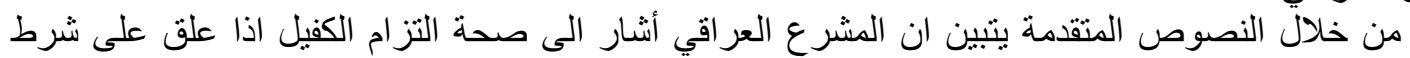

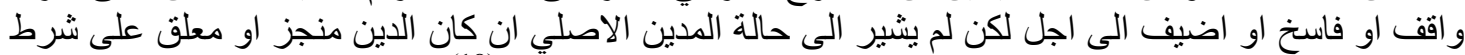

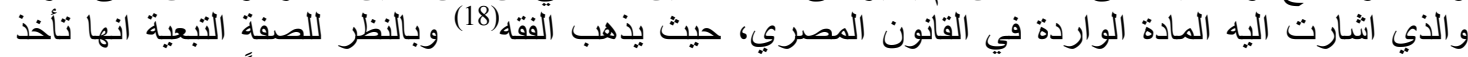

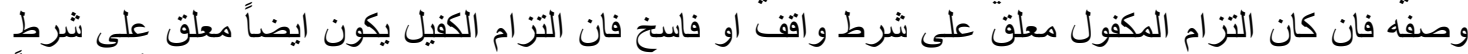

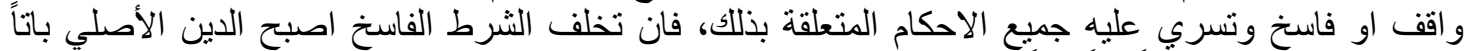

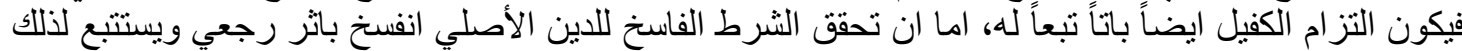

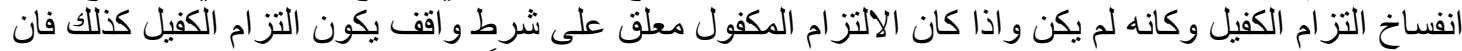

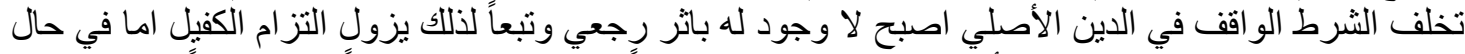

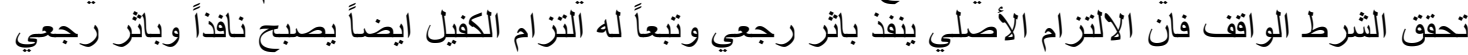
وتسري عندها احكام الكفالة.

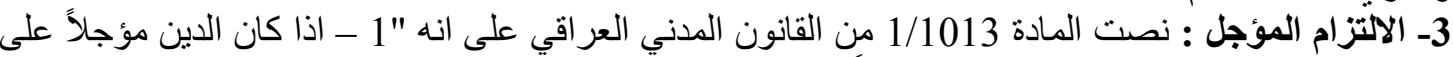

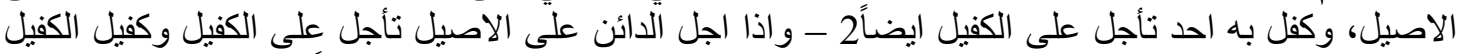

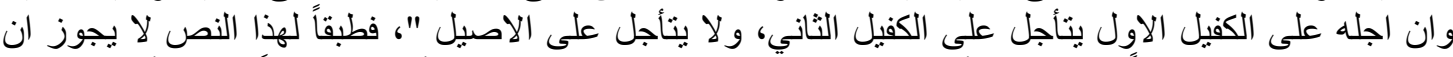

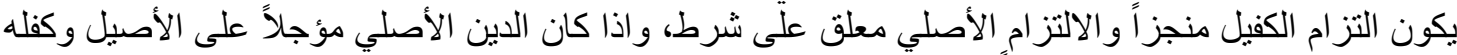

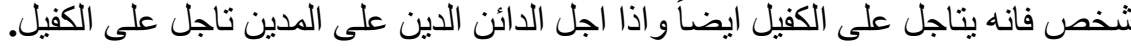

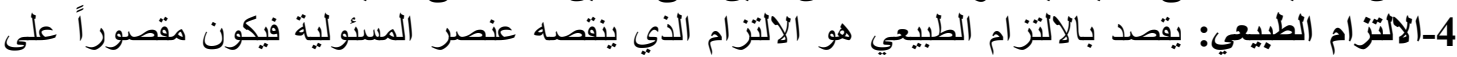

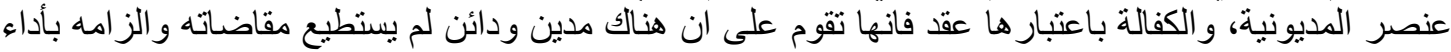

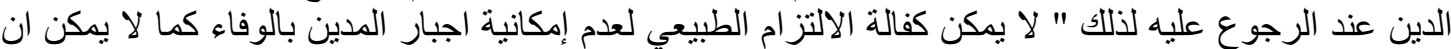

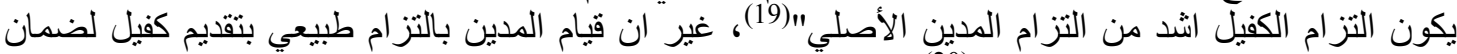

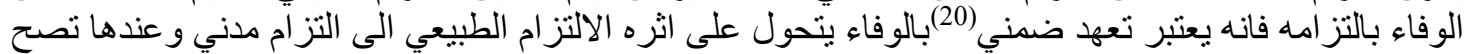

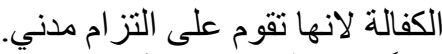

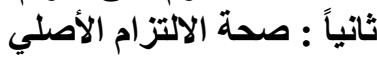

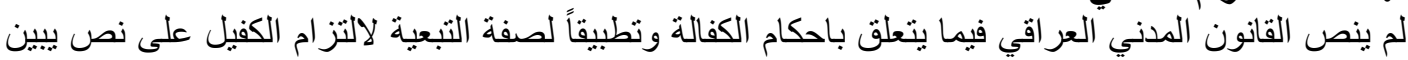

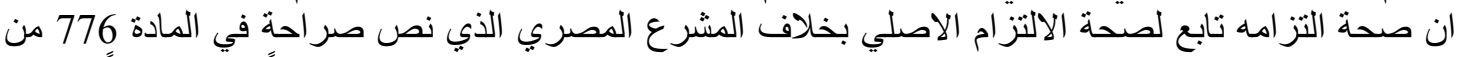

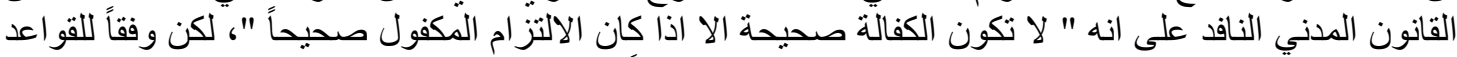

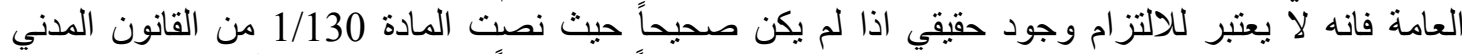

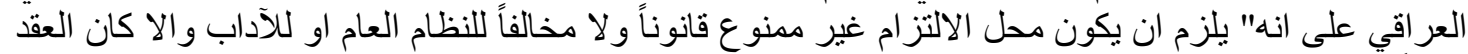

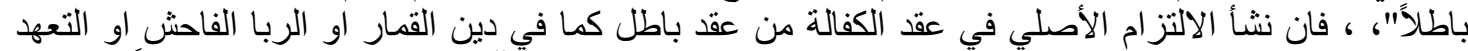

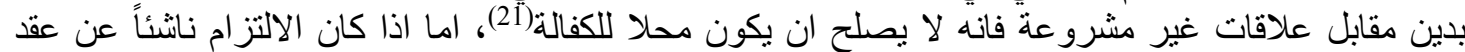

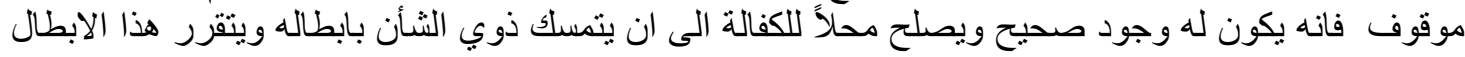




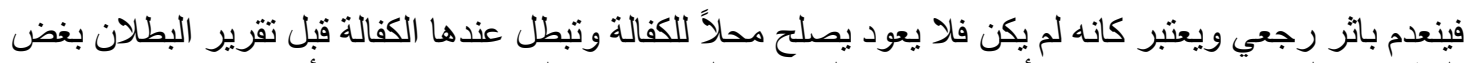

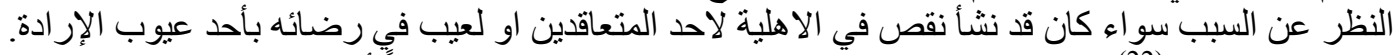

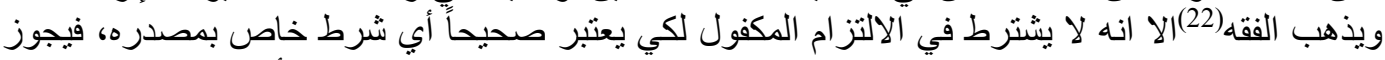

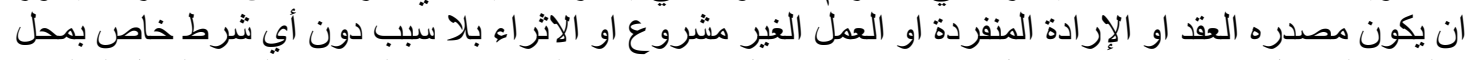

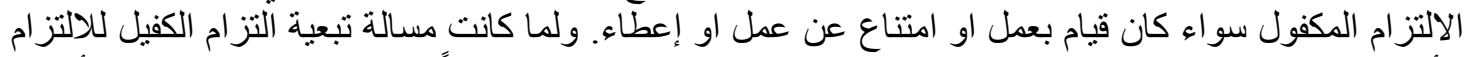

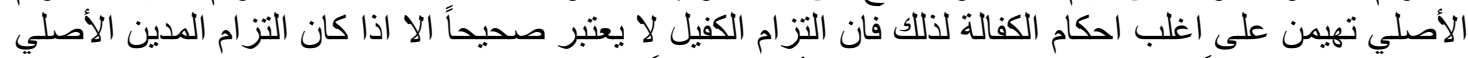

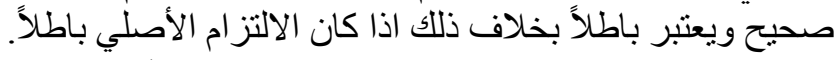

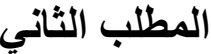

\section{نطاق التزام الكفيل بالنظر لَّفته التبعية}

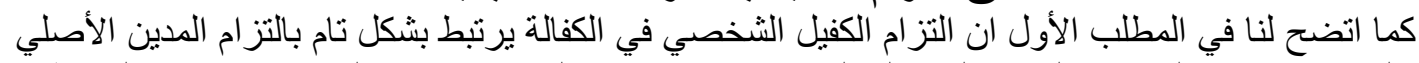

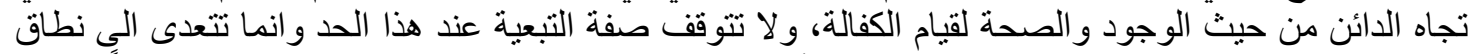

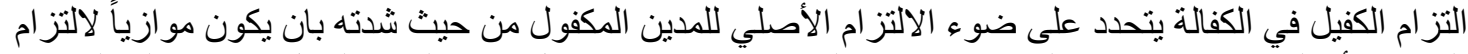

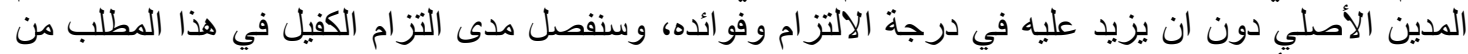

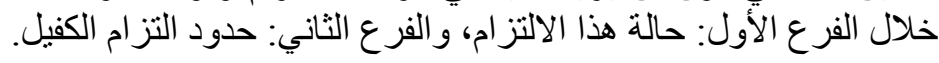

\section{الفرع الأول حالة التزام الكفيل}

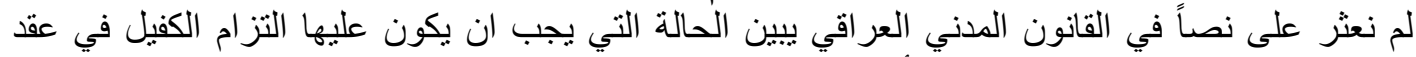

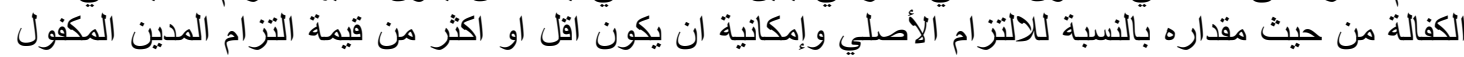

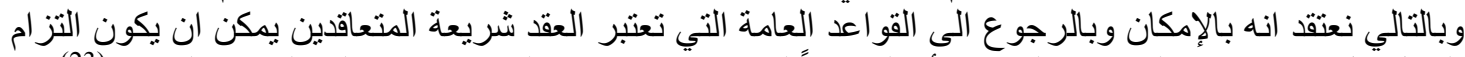

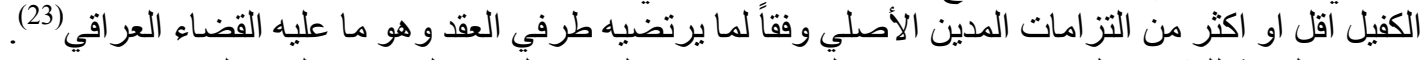

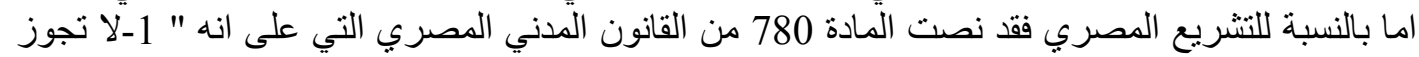

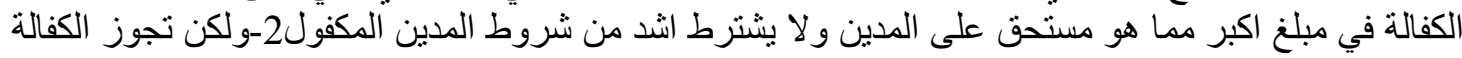

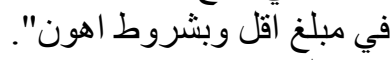

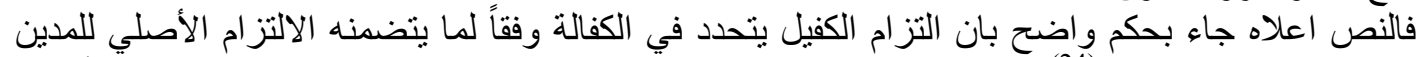

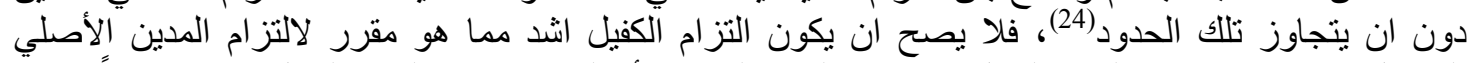

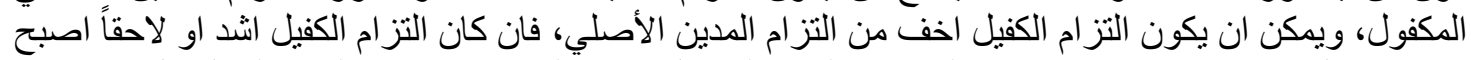

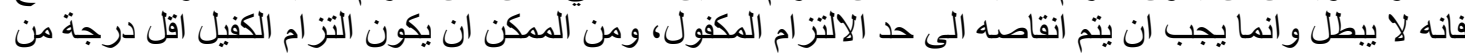

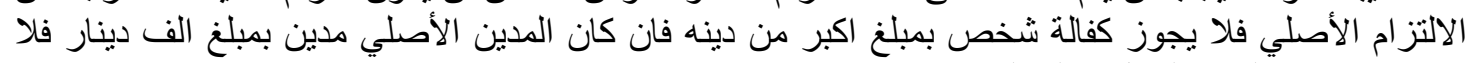
يجوز ان يكون التز ام الكفيل بمبلغ الف وفلف ومائتان دينار.

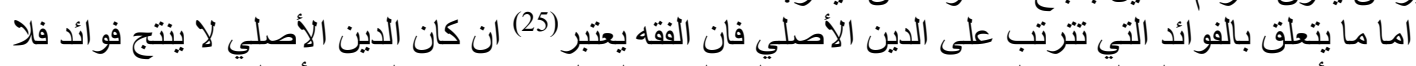

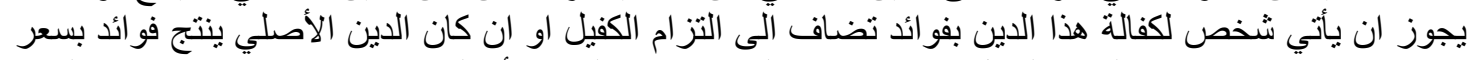

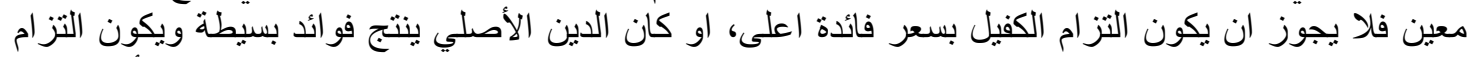

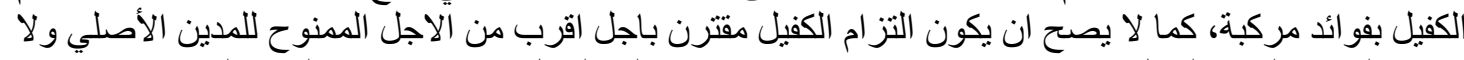

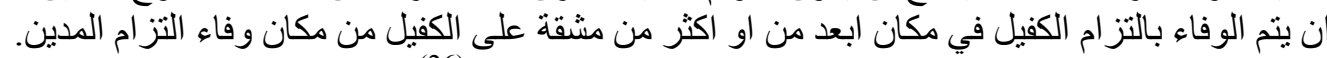

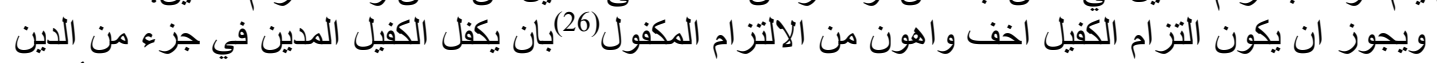

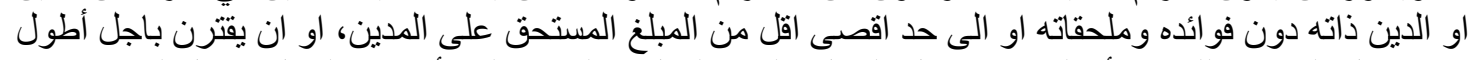

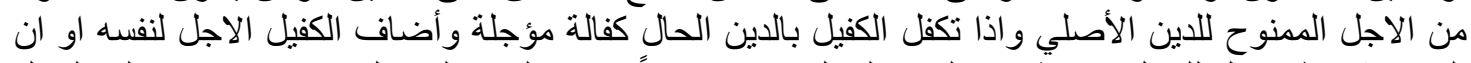

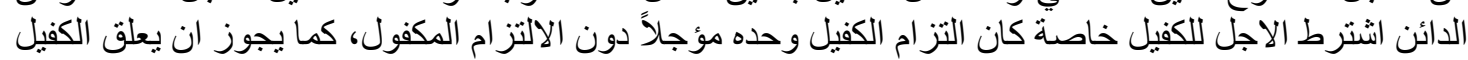

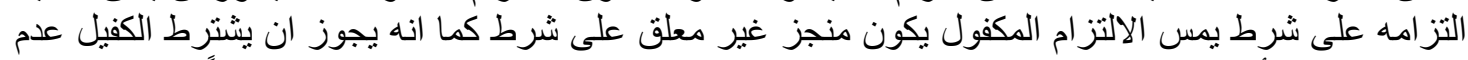

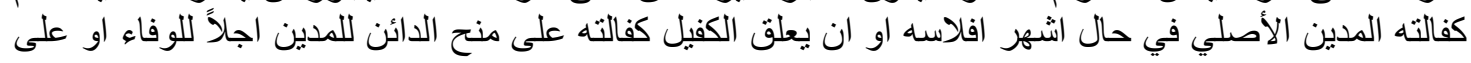


وجود ضمانات أخرى للمدين غير الكفالة او على استعمال المدين للدين استعمالاً معيناً او لهدف معين فان تخلف الشرط فيما سبق زات الت الكفالة.

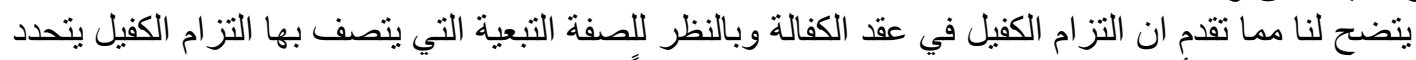

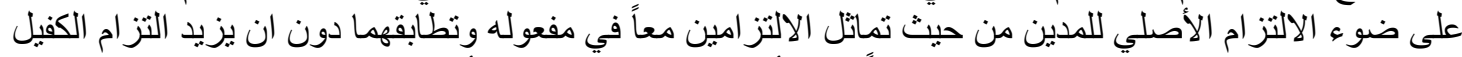

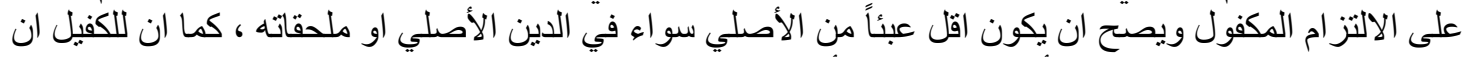

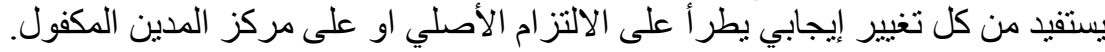

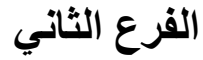 \\ حدود التزام الكفيل}

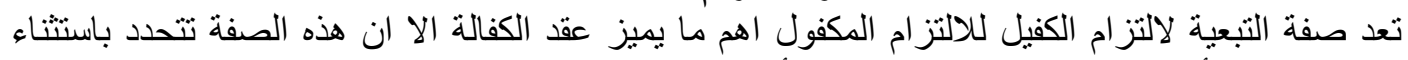

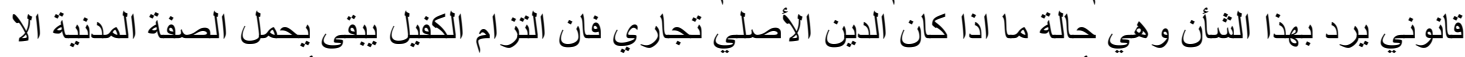

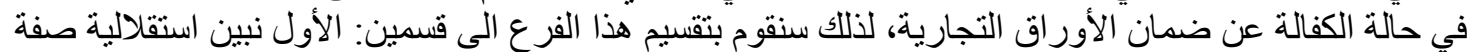

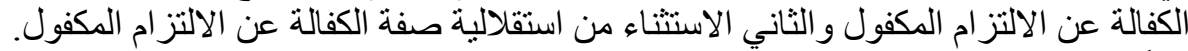

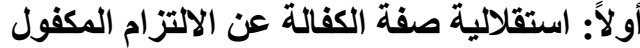

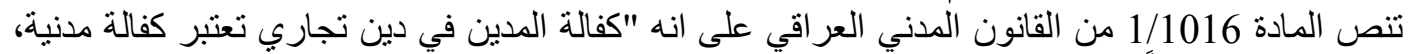

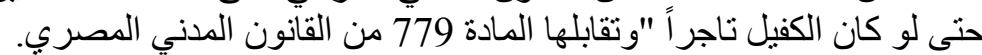

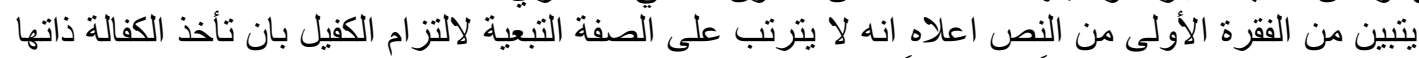

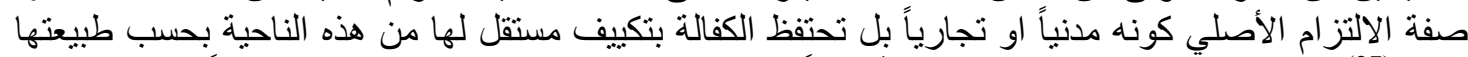

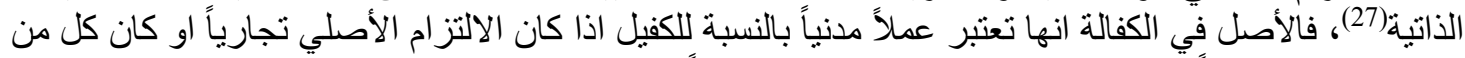

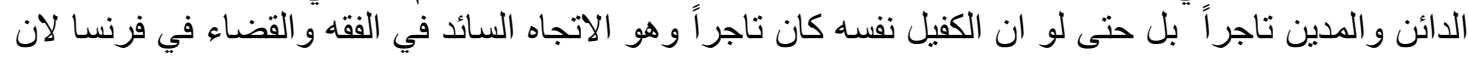

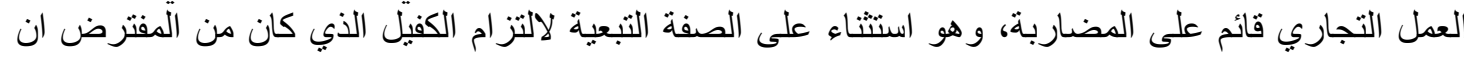

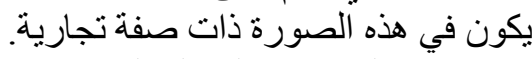

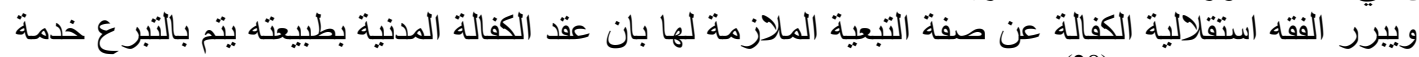

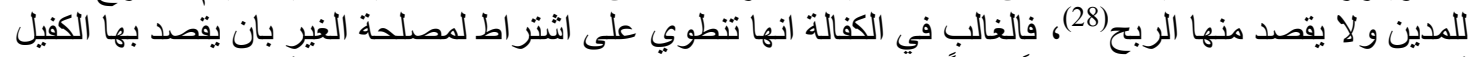

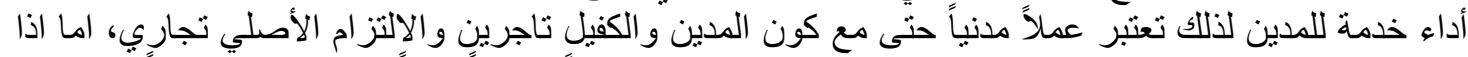

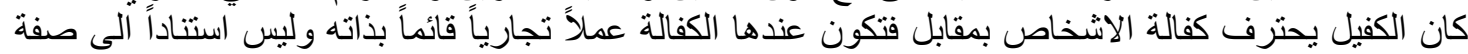

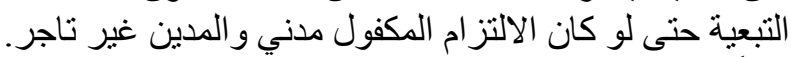

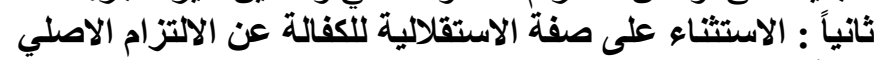

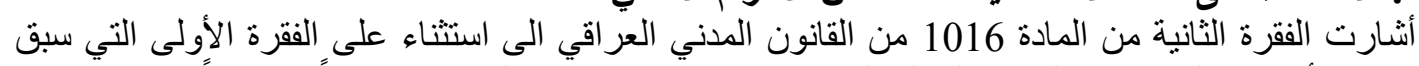

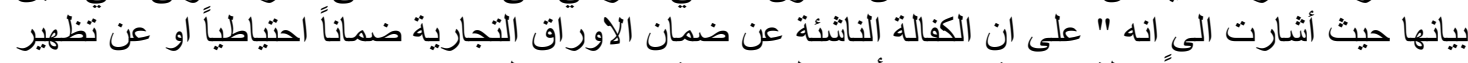

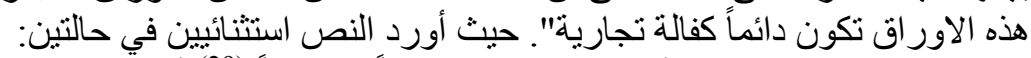

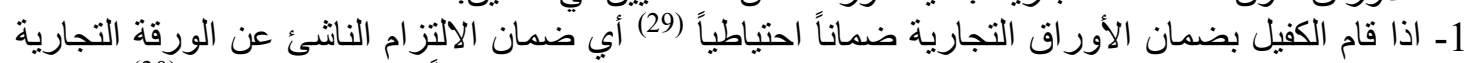

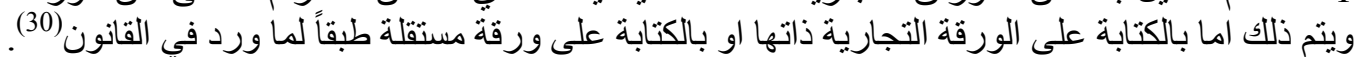

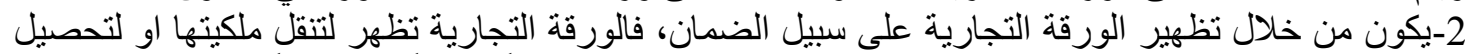

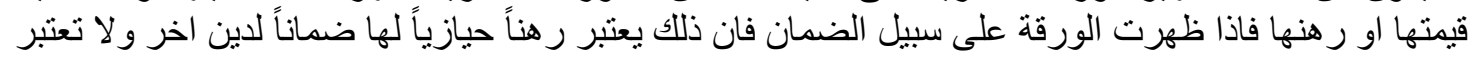

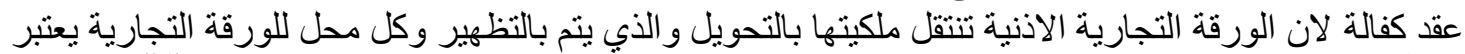

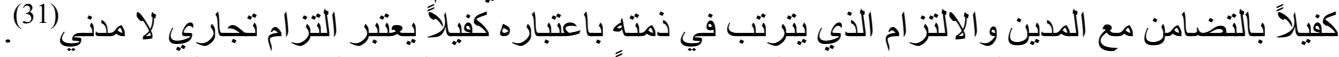

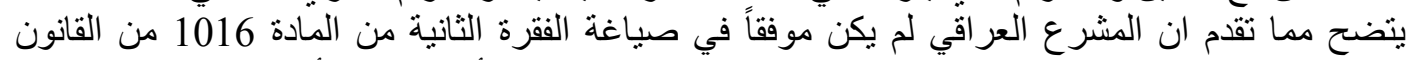

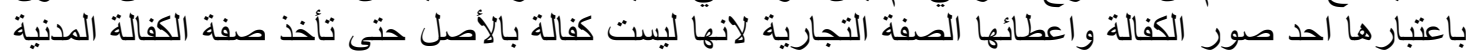

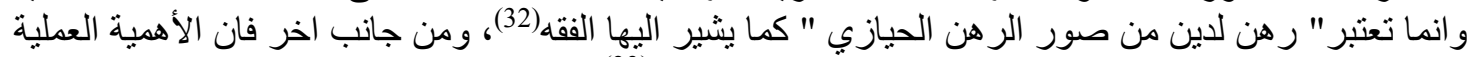

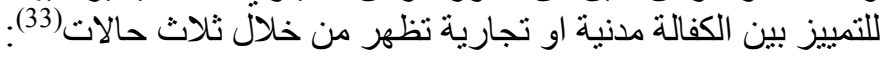

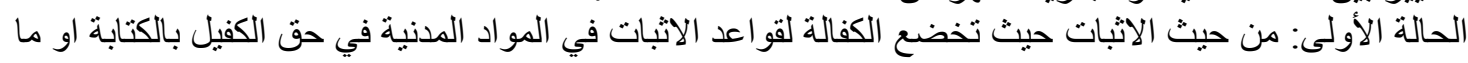

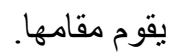


الحالة الثانية: من حيث الاختصاص القضائي: فتكون المحكمة المدنية هي المختصة اذا كان اذا كان الكفيل هو

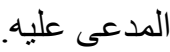
الحالة الثالثة: من حيث استحقاق فو ائد التأخير على الكفيل فإنها تحتسب بالسعر الذي يسري على الديون المدنية

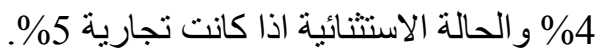

\section{المبحث الثاني \\ اثار الصفة التبعية على ألتزام الكفيل التاني}

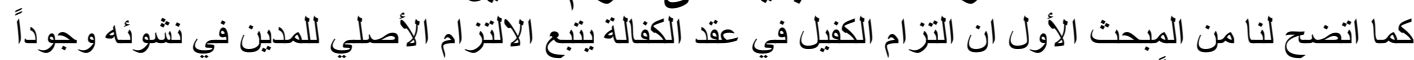

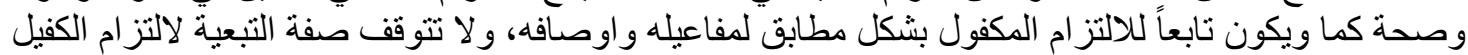

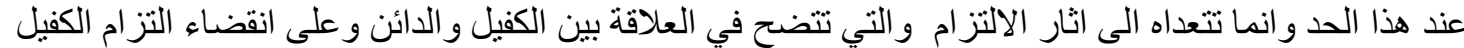

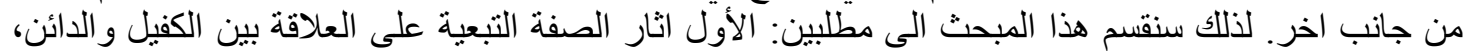

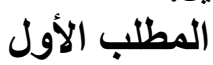
و الثاني: اثار الصفة التبعية على انتهاء التز ام الكفيل.

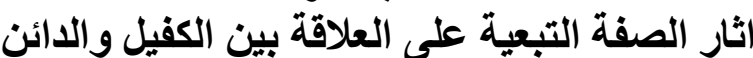

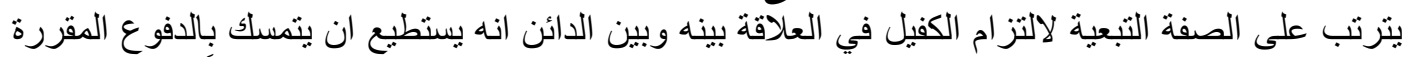

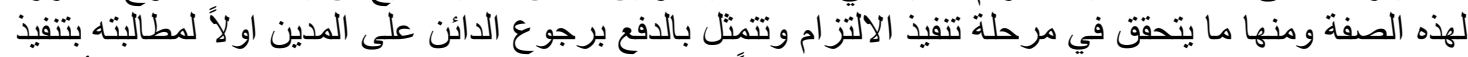

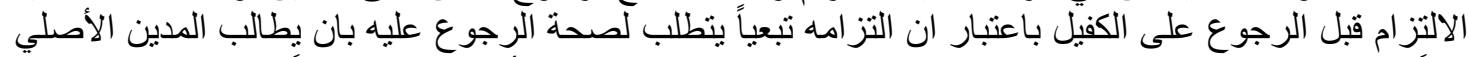

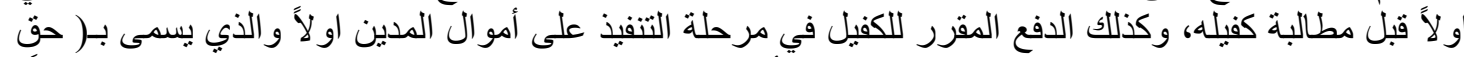

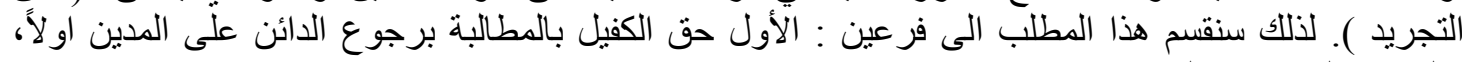

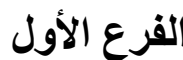

\section{حق الكفيل بالمطالبة برجوع الأائن على المدين اولاً}

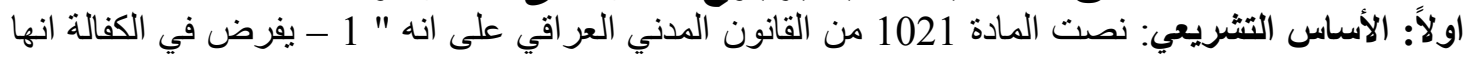

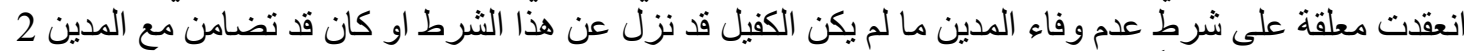

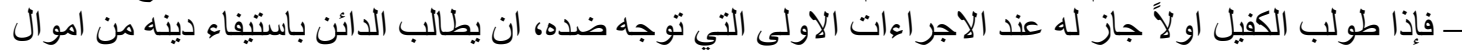

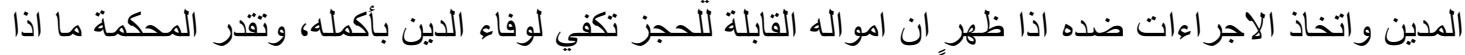

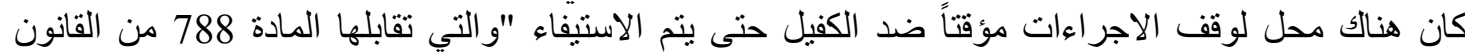

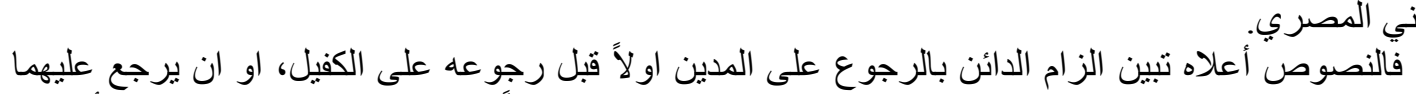

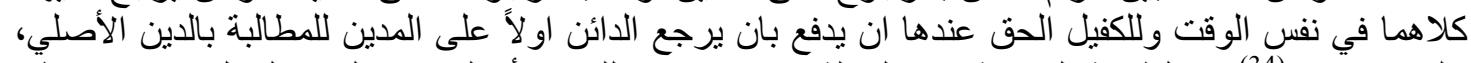

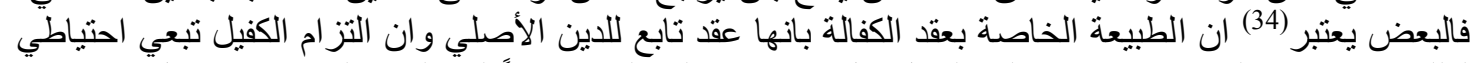

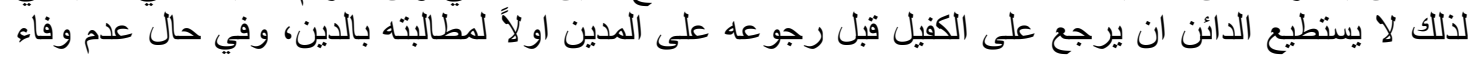

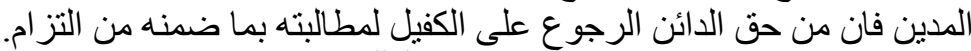

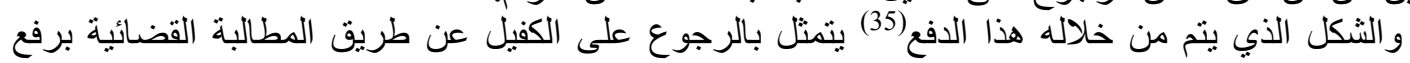

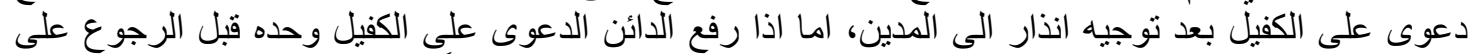

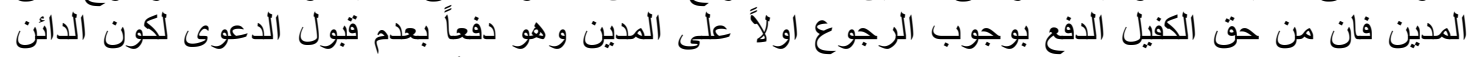

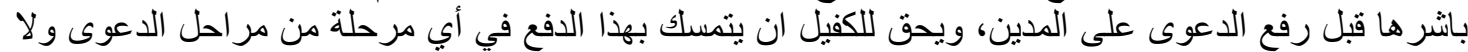

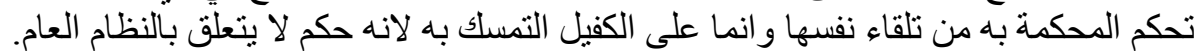

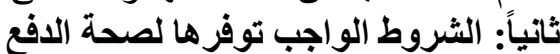

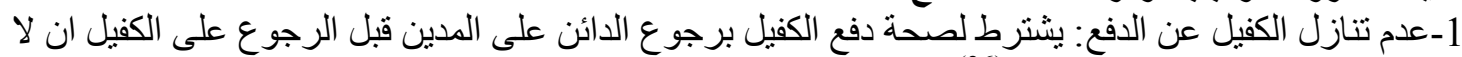

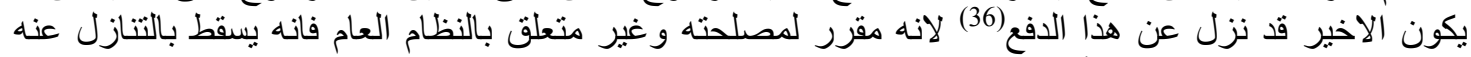
بشكل صريح او ضمني وفي أي مرحلة من مر احل عقد الكفالة. 


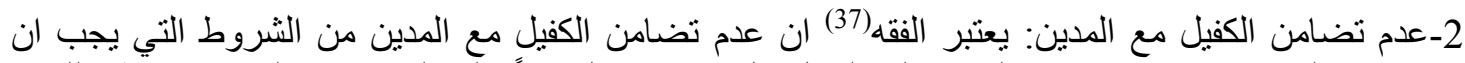

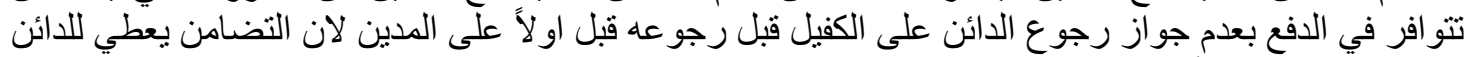

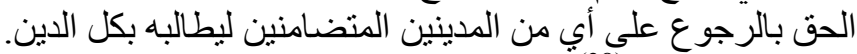

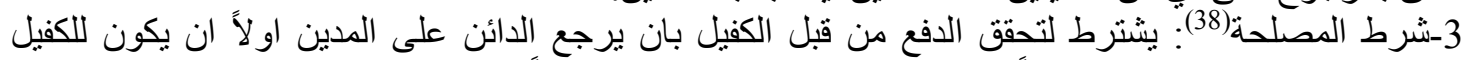

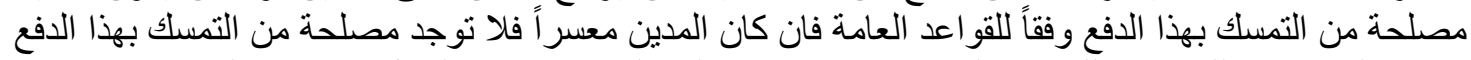

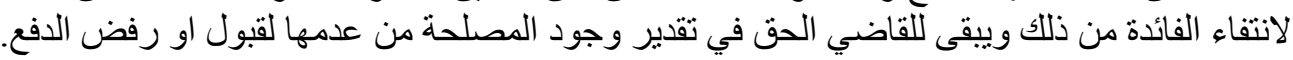

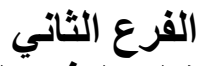

\section{حق الكفيل بالافع بـالتجريا}

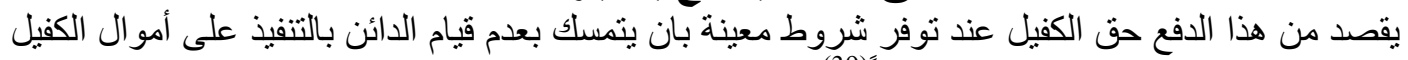

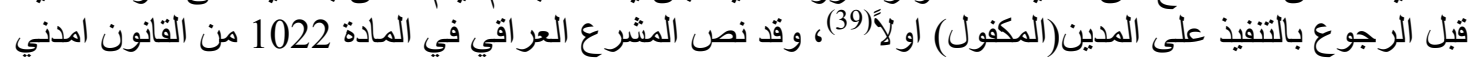

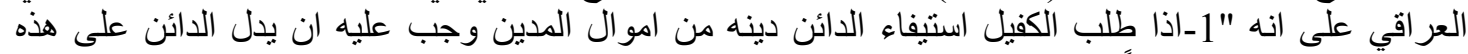

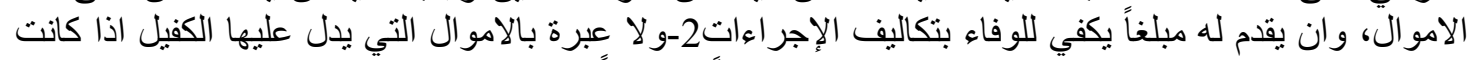

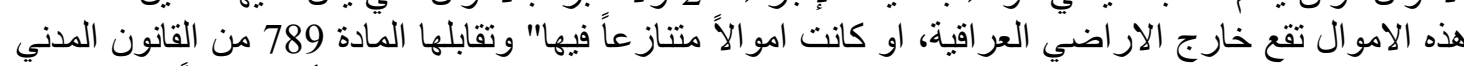

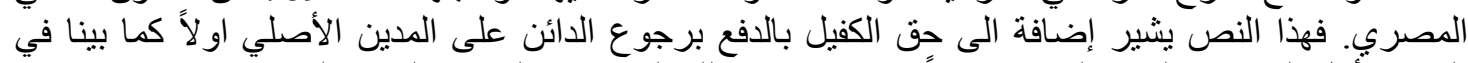

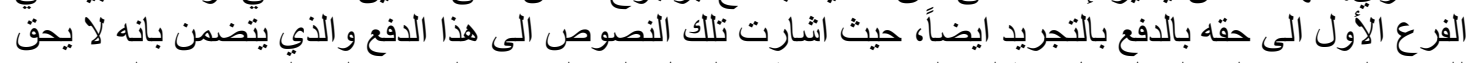

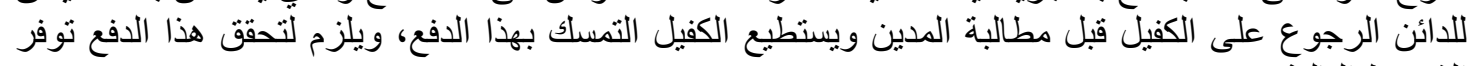

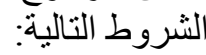

اولاً: الثروط الخُّة: الخاصة بالكفيل وهي:

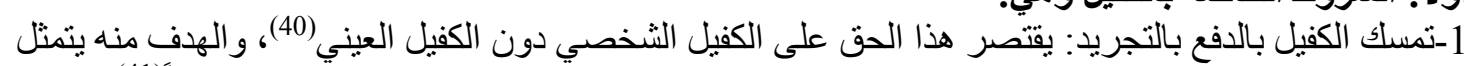

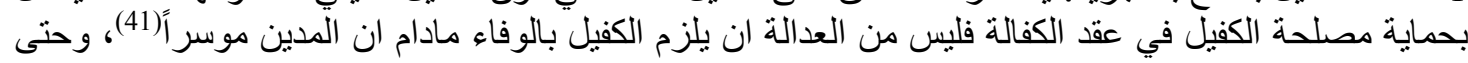

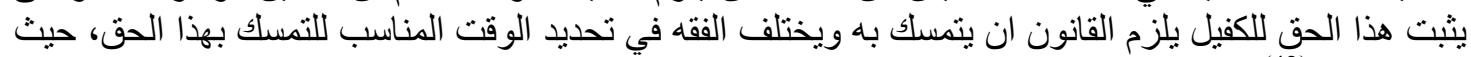

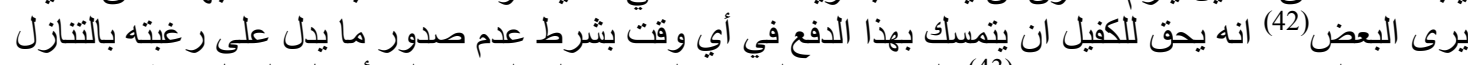

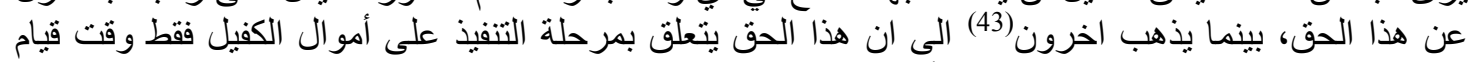

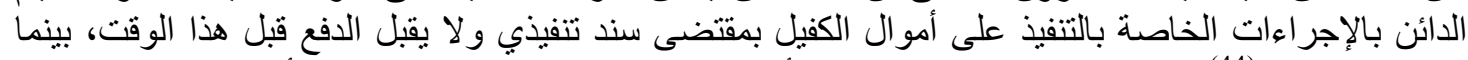

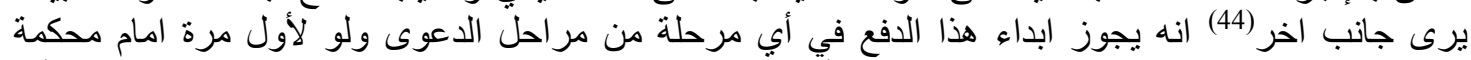

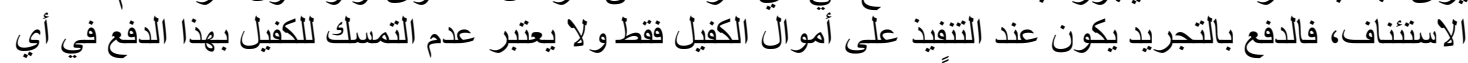

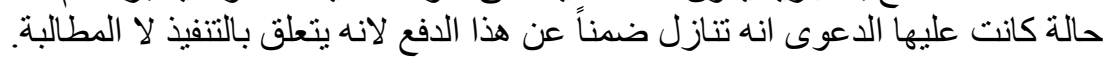

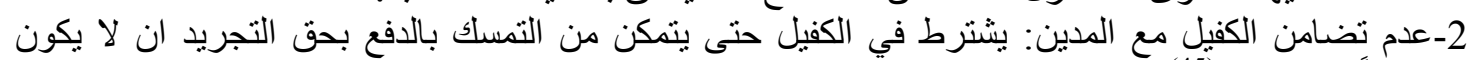

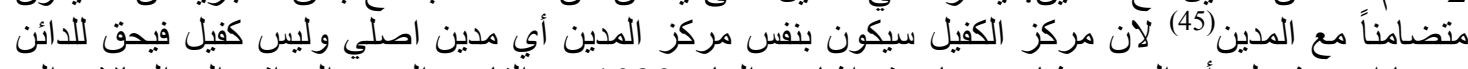

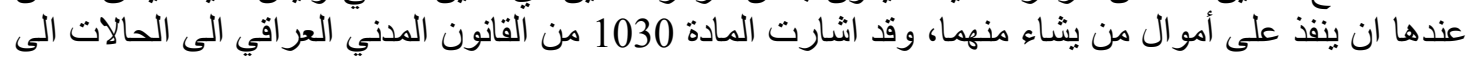

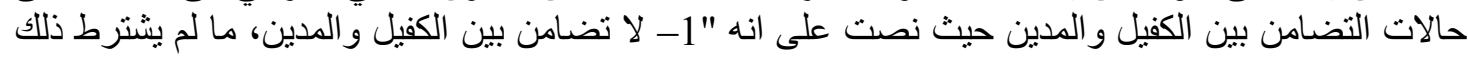

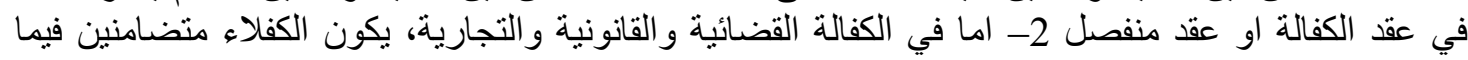

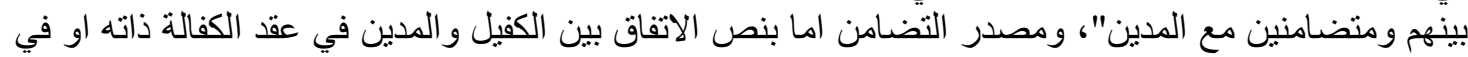

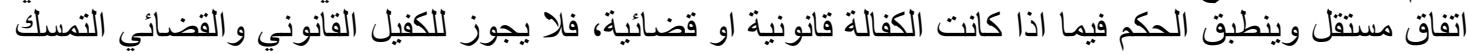

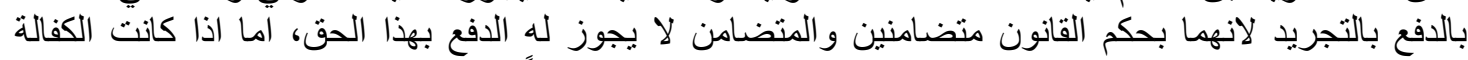

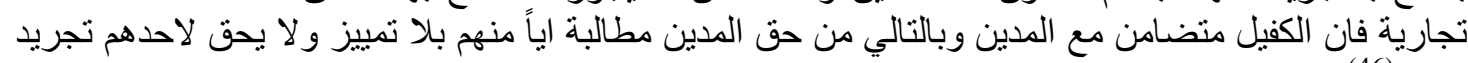

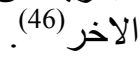

3- عدم النتازل عن الحق بالدفع بالتجريد(47): يعتبر الحق في التجريد حق خاص بالكفيل ولمصلحته فيحق له بله

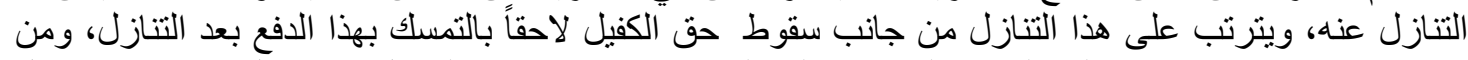

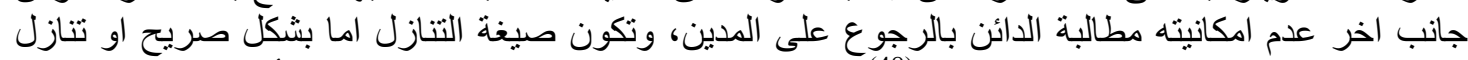

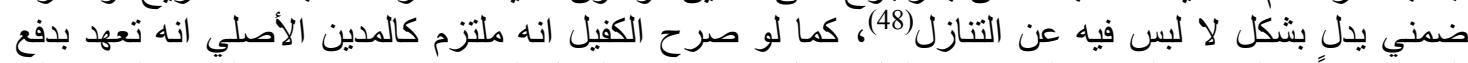

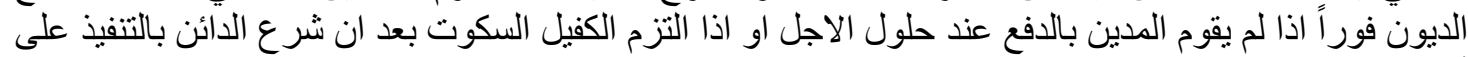
أمو اله دون ان يبدي المدين الدفع بالتجريد. 
ثانياً: الثروط التي تثتلق بأموال المدين

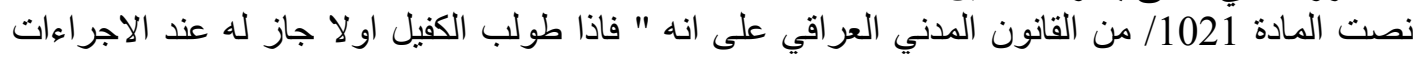

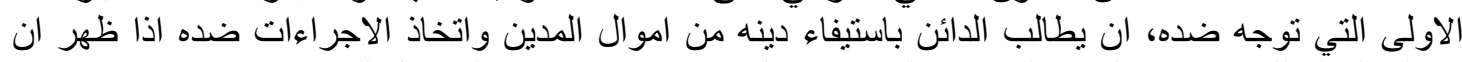

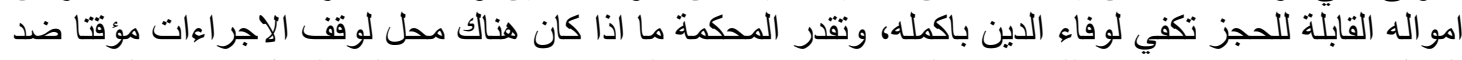

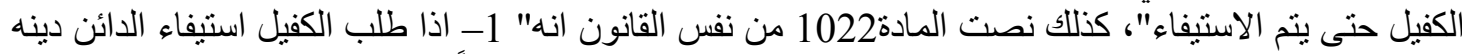

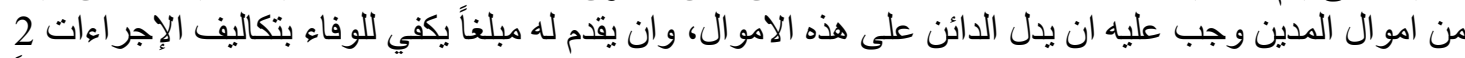

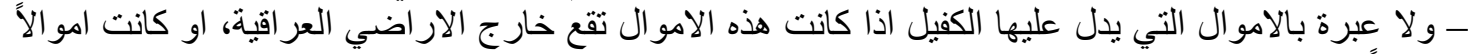

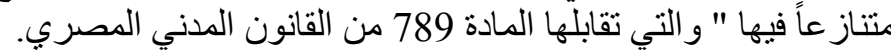
يتبين من النصوص فئل أعلاه ان القانون يشترط في أمو ال المدين فيما يتعلق بحق الكفيل بالدفع بالتجريد ان تتو افر

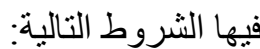

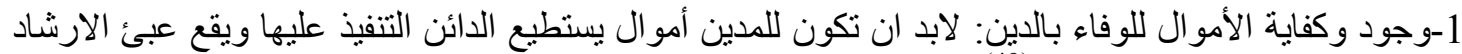

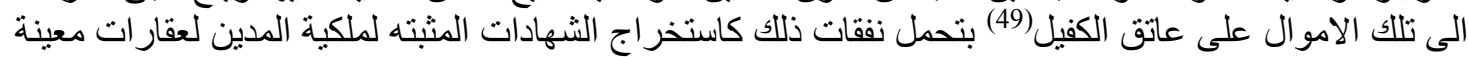

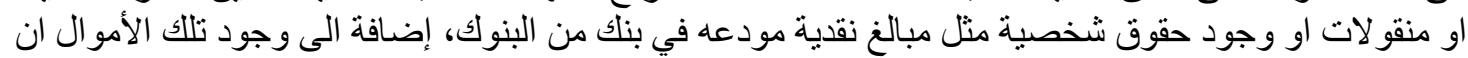

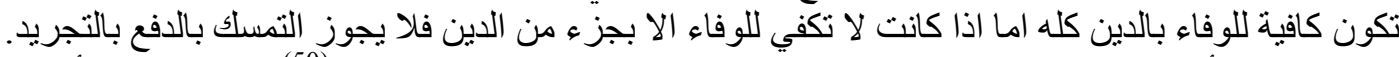

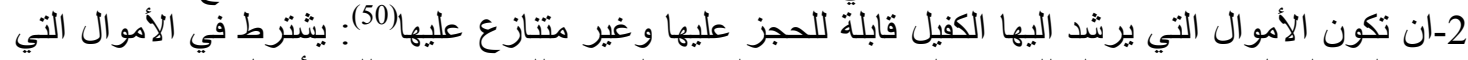

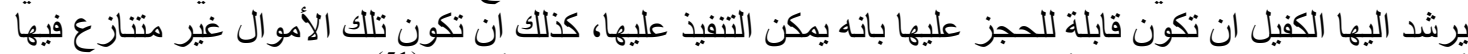

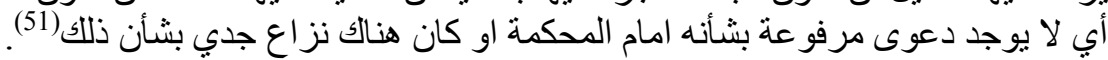

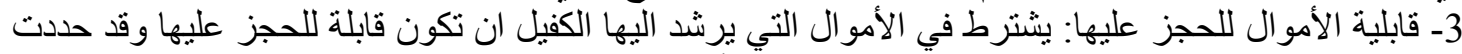

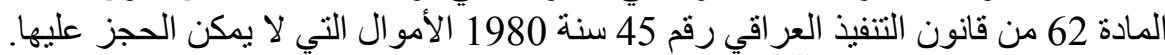

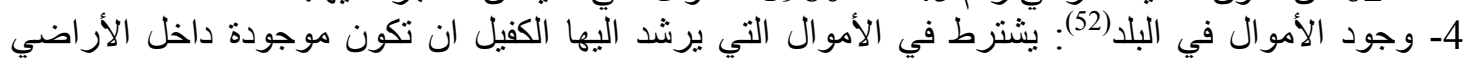

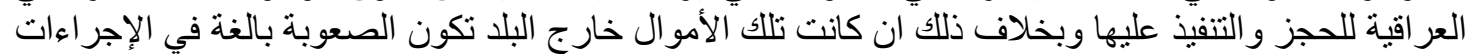

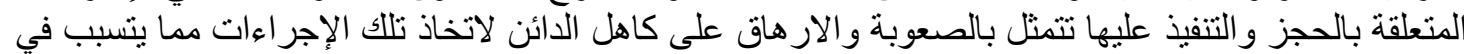

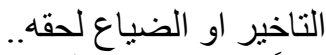

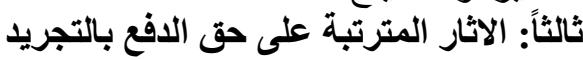

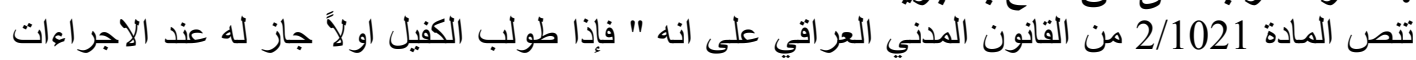

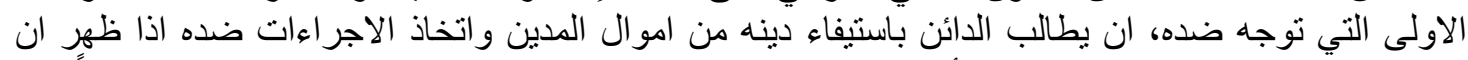

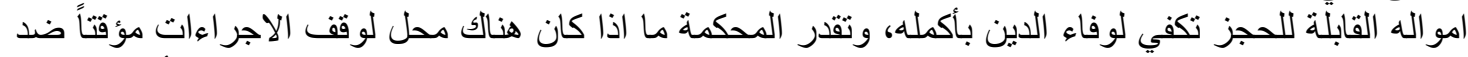

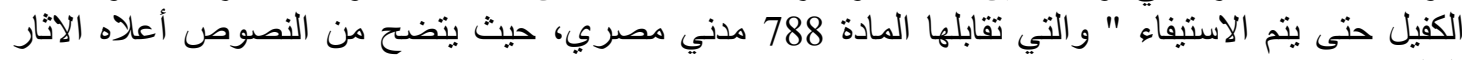
التالية: 1-وقف إجر اءات التنفيذ: والتي تثير الى عدم جواز التنفيذ على أمو ال الكفيل الا بعد تجريد المدين من أمو اله دون

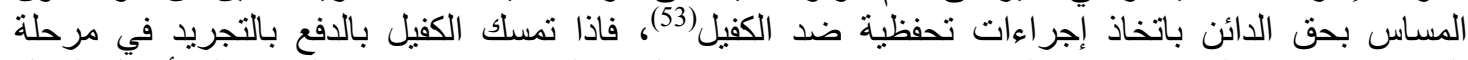

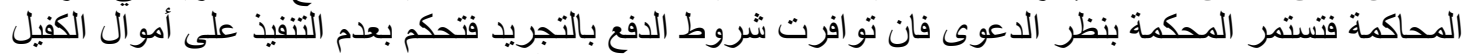

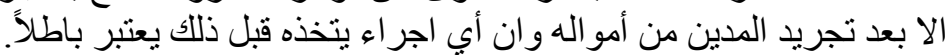

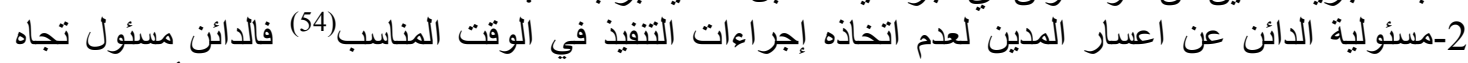

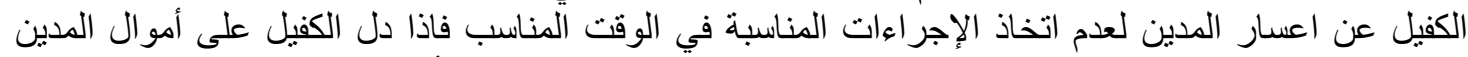

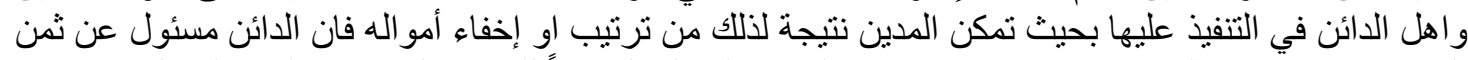

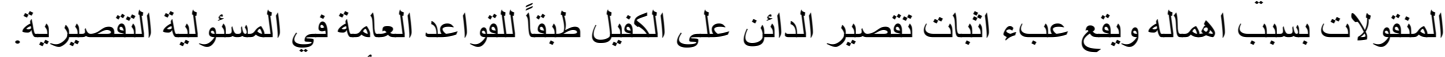

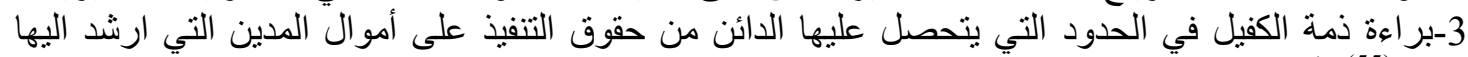

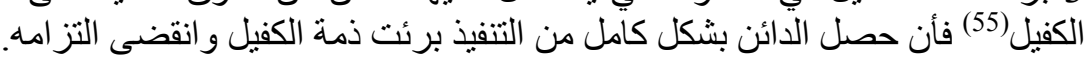
المطاب الثاني

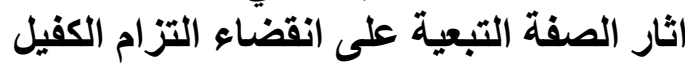

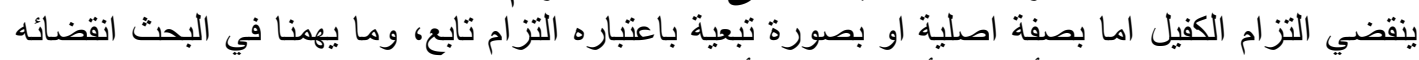

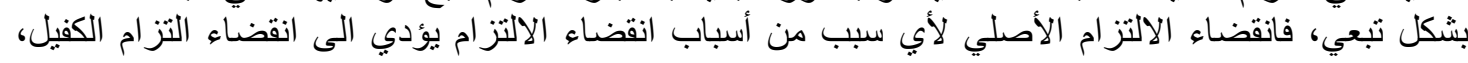




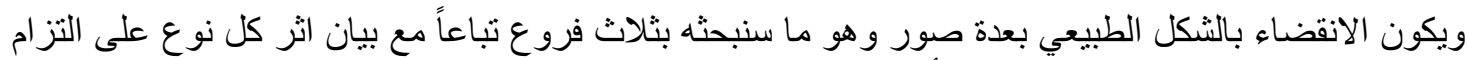

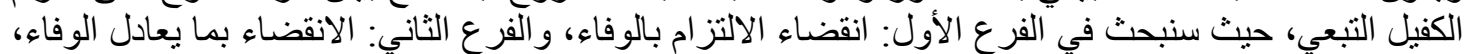

\section{الفرع الأول

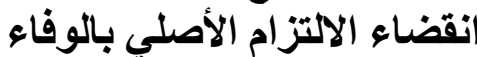

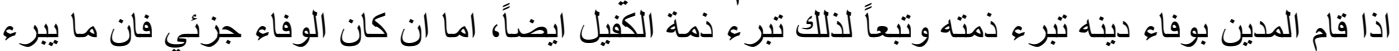

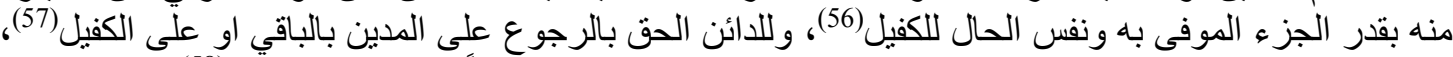

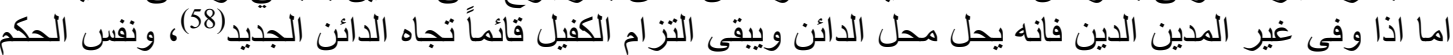

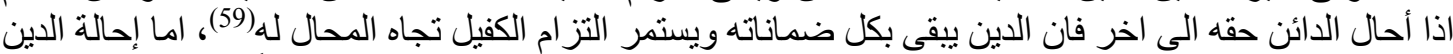

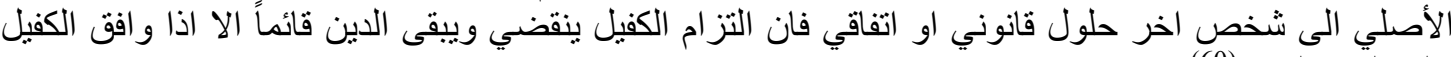
على الدين الجديد (60).

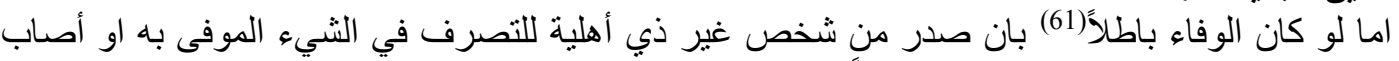

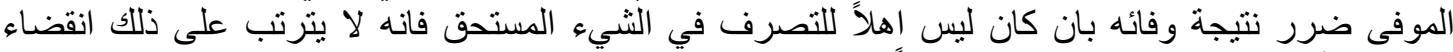

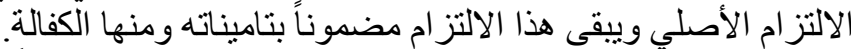

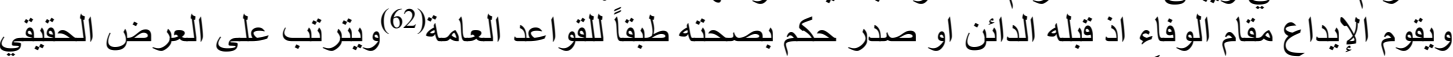

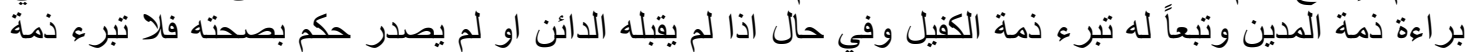

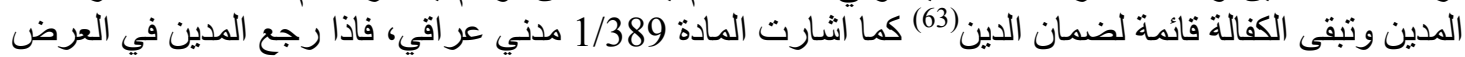

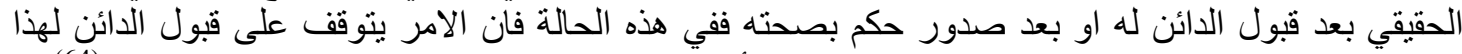

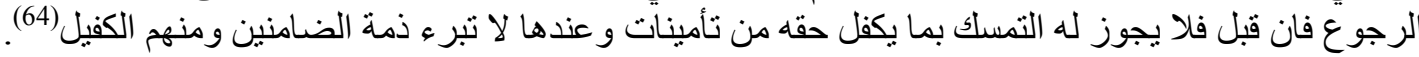

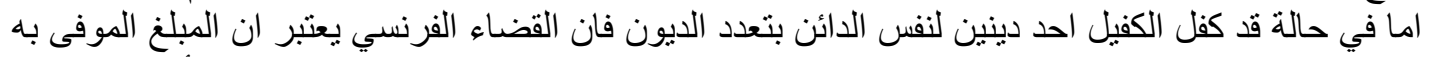

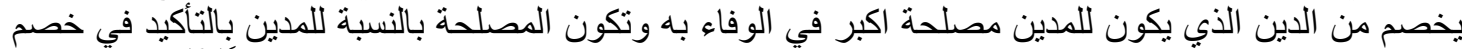

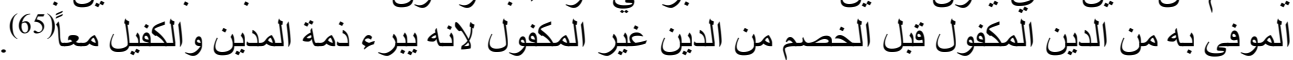

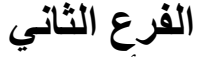

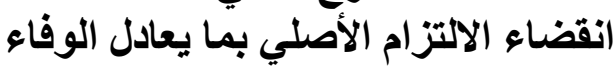

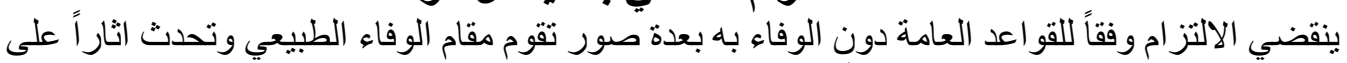

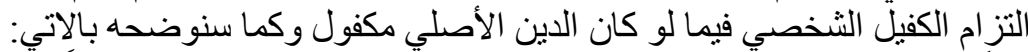

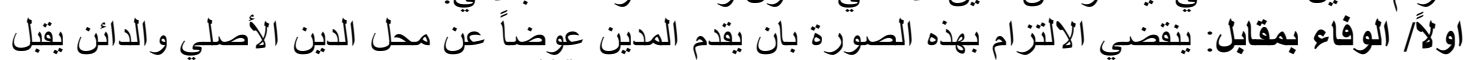

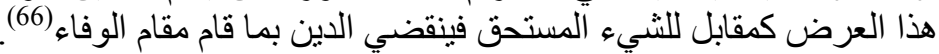

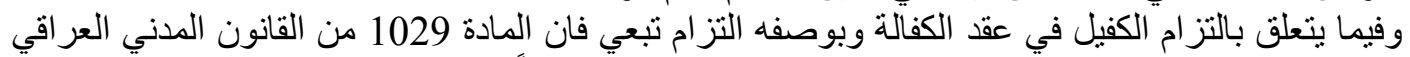

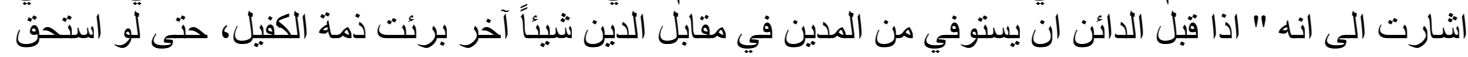

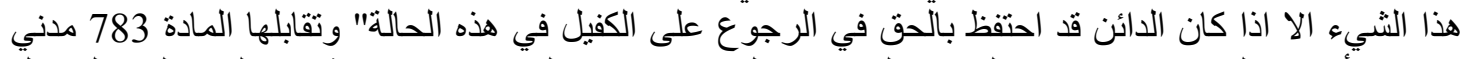

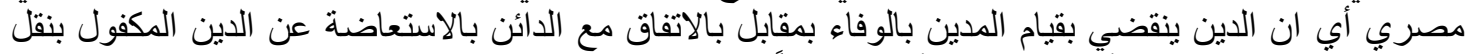

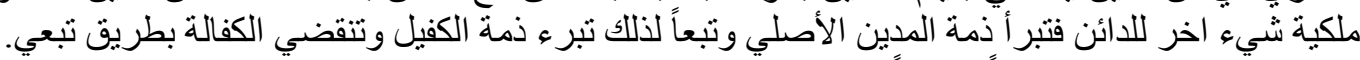

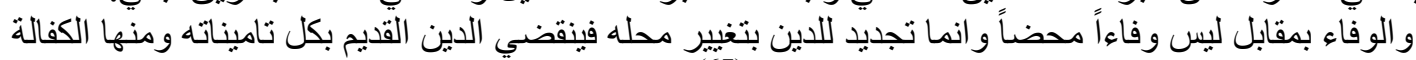

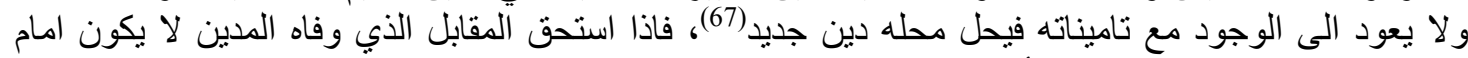

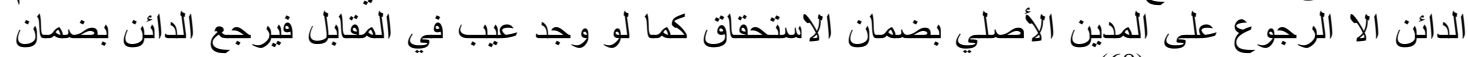

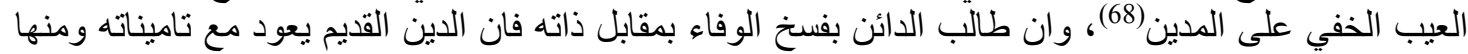

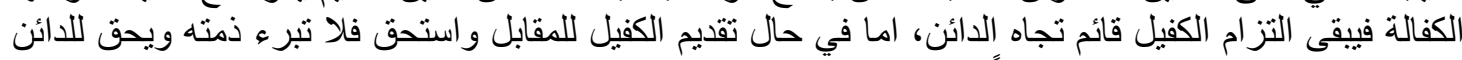

الرجو ع عليه بضمان الاستحقاق و فقاً للقو اعد العامة التهة

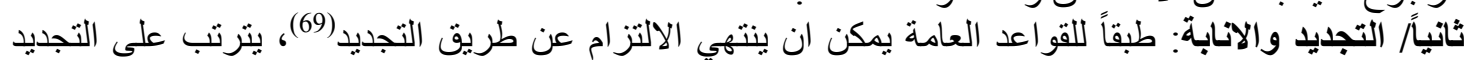

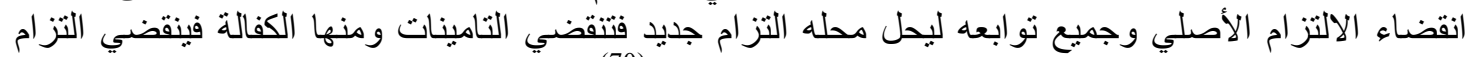

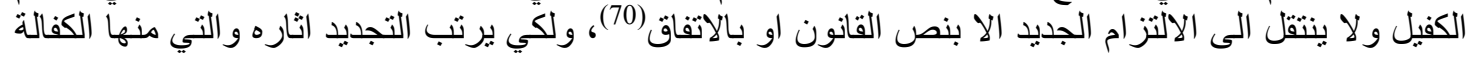




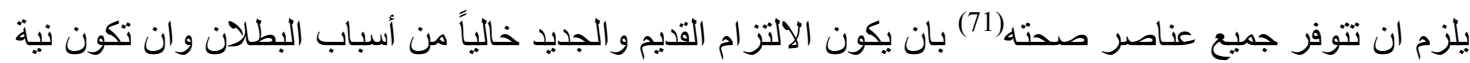

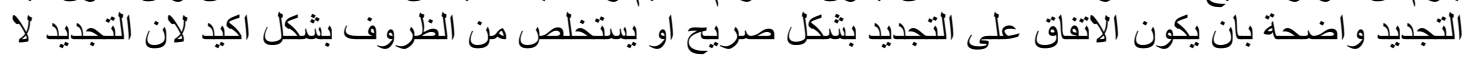

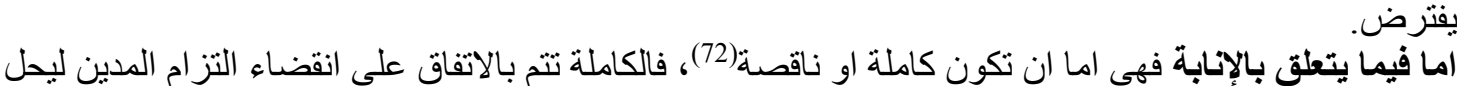

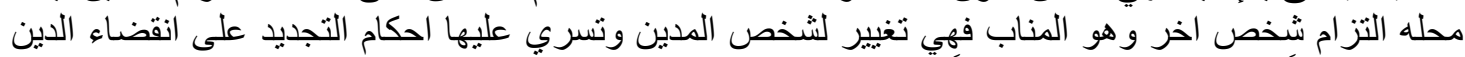

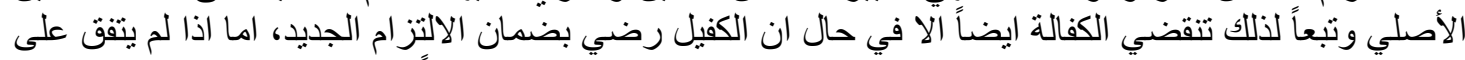

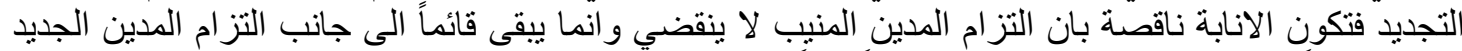

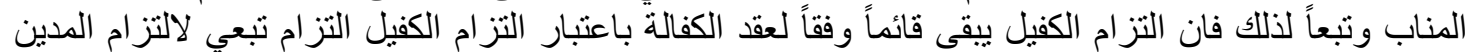

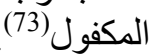
ثالثار المقاصةً : ينقضي الدين وفقاً للمقاصة اذا اصبح المدين دائن لدائنه فينقضي الدينين بالأقل منهما(74) وبقوة

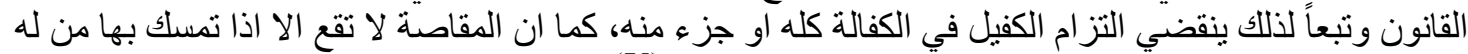

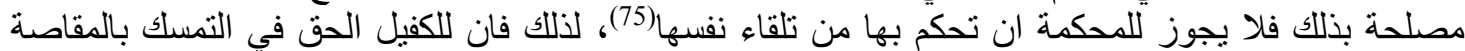

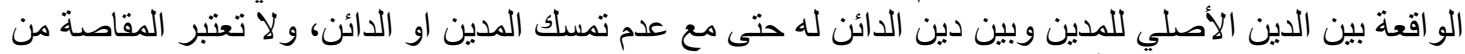

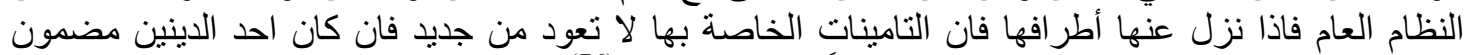

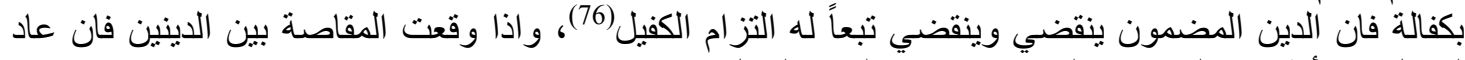

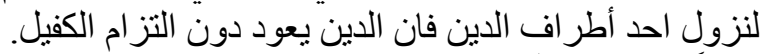

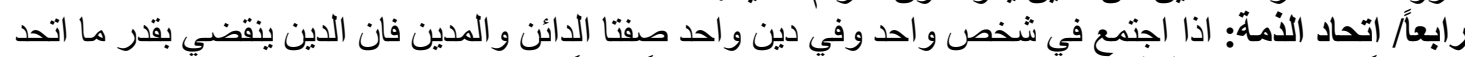

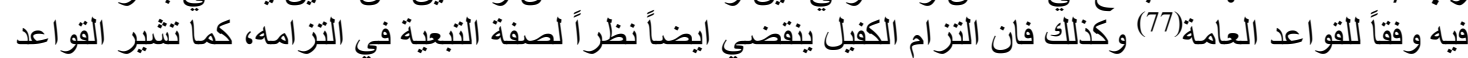

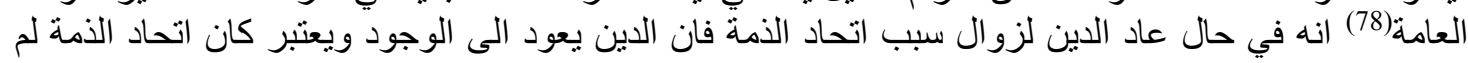

\section{القزم الثرع الثالث}

يكن.

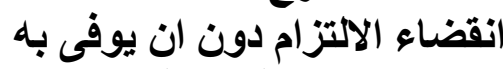

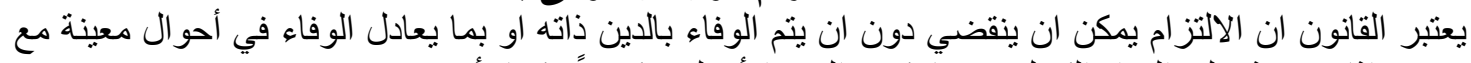

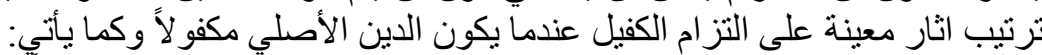

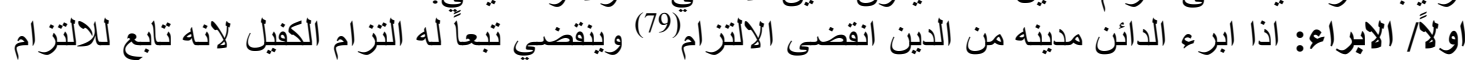

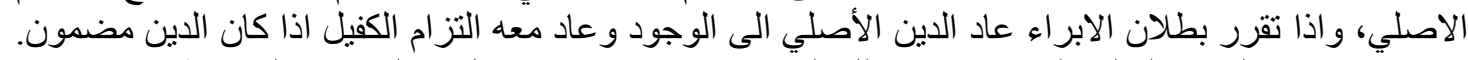

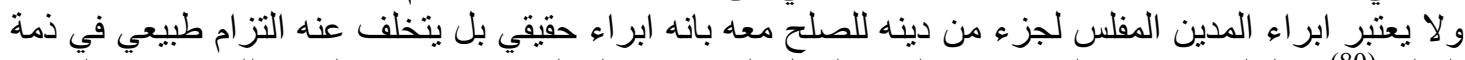

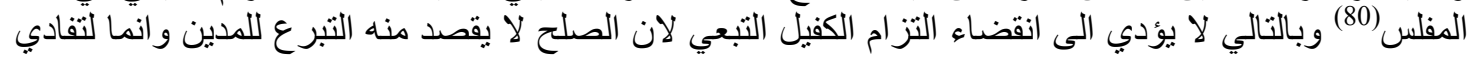

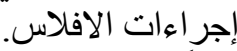

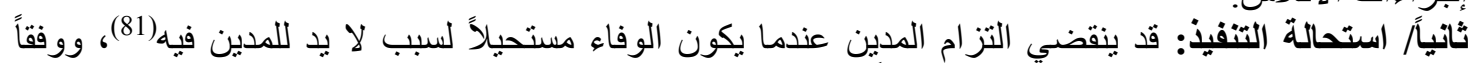

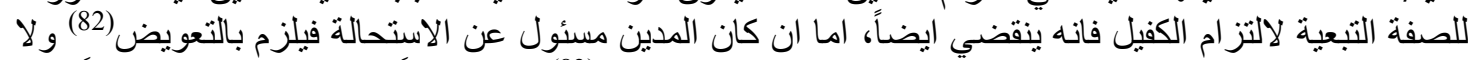

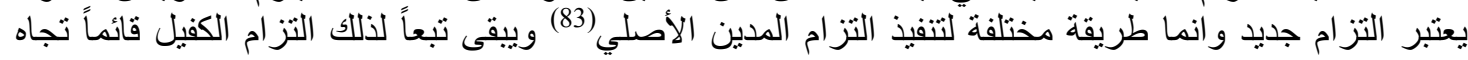

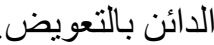

تُالثاًر التقادم: يترتب على احكام التقادم العديد من الاثار التي تمس التزام الكفيل بالنظر لصفته التبعية وكما بينها

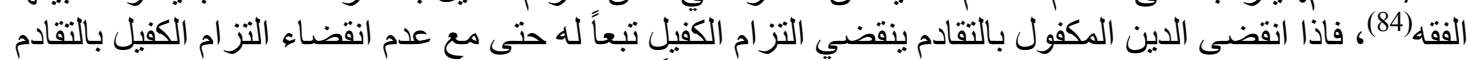

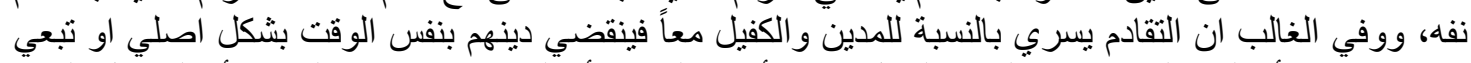

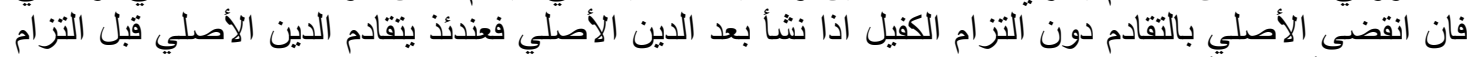

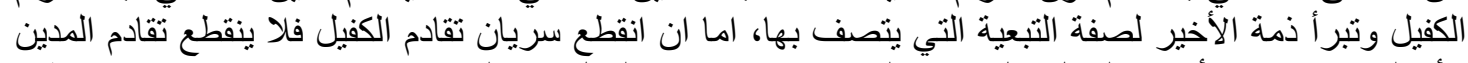

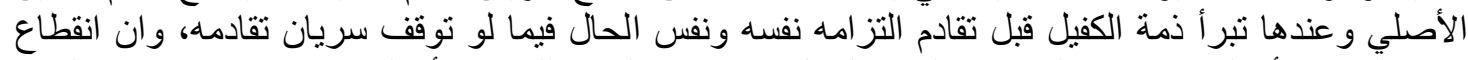

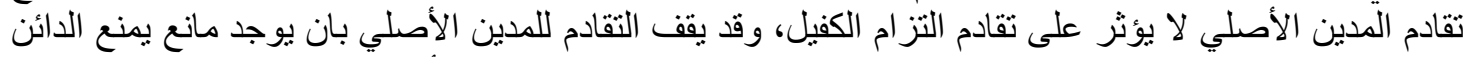

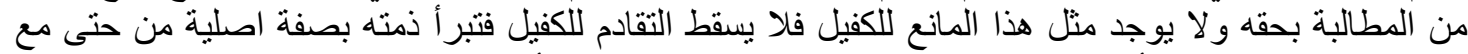

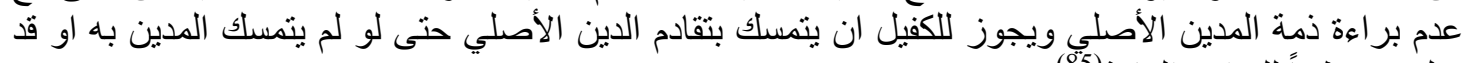
نزل عنه طبقاً للقو اعد العامة (85). 


\section{العدد (23) أغطط 2021 Volume (23) August 2021}

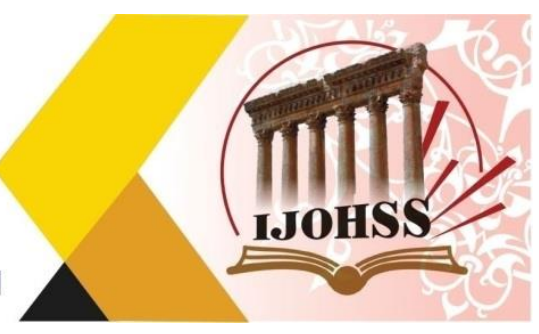

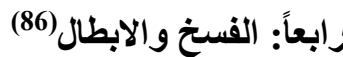

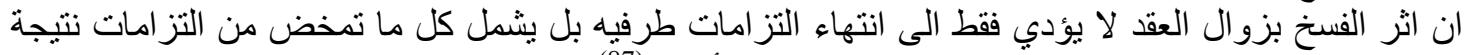

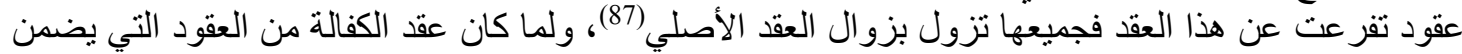

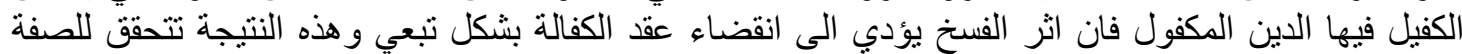
التبعية التي يتصف بها الاين التكها التز ام الكفيل.

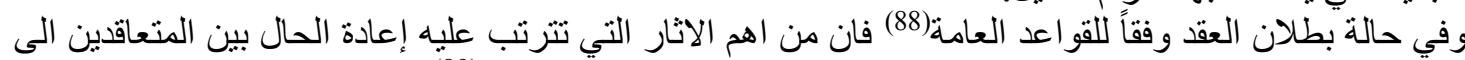

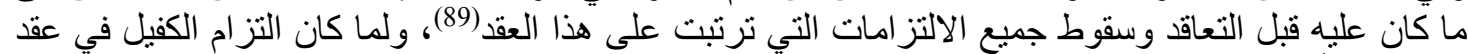

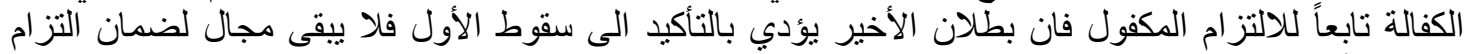
المدين الأصلي الذي انقضى بفعل البطلان.

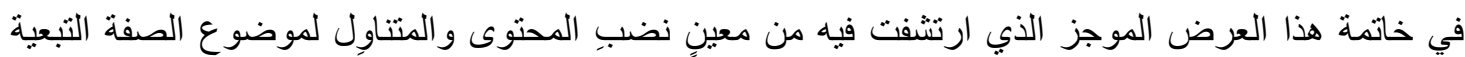

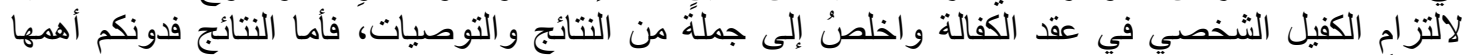

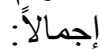

اولاًا : النتائج : التزان

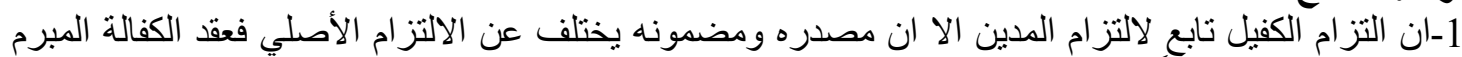

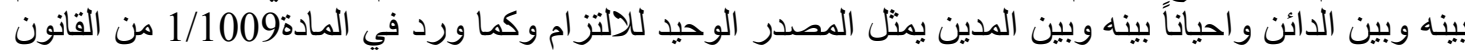

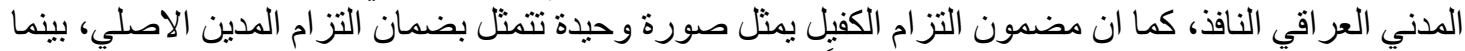

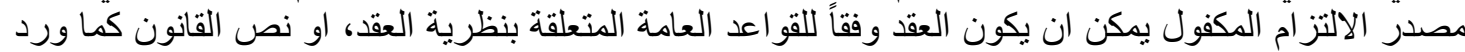

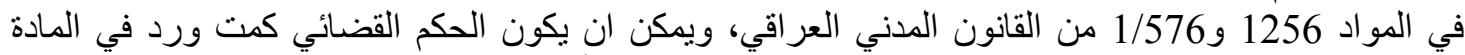

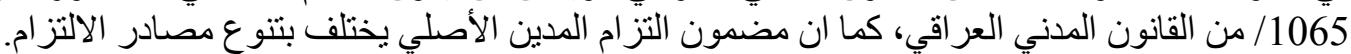

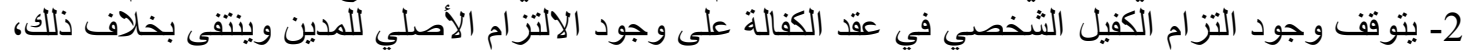

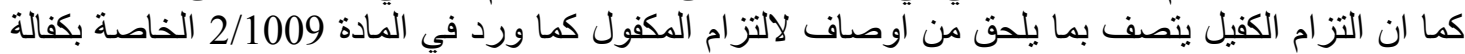

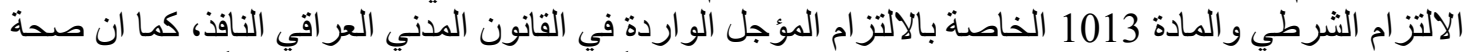

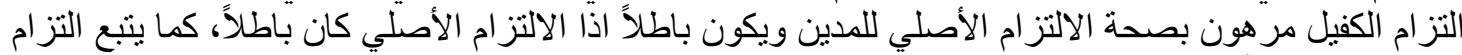

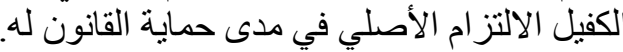

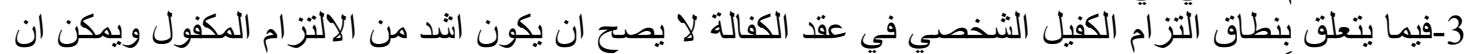

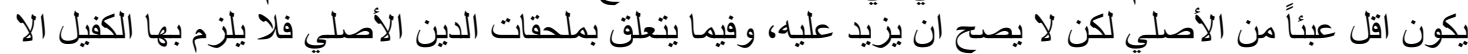

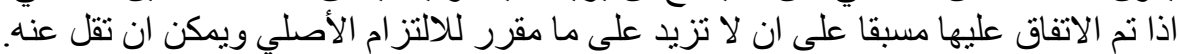

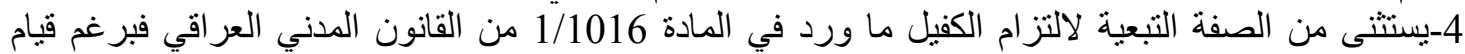

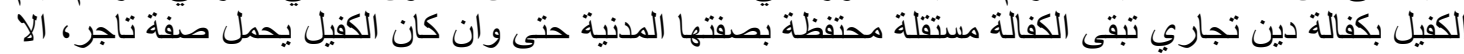

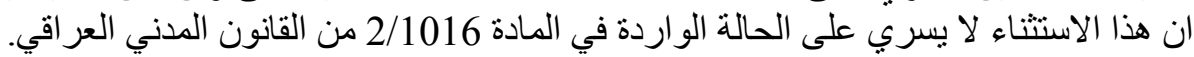

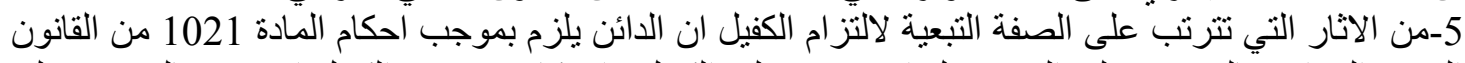

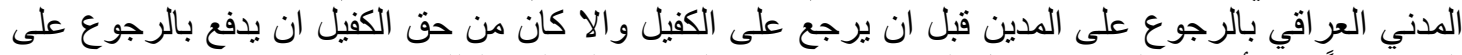

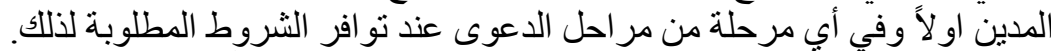

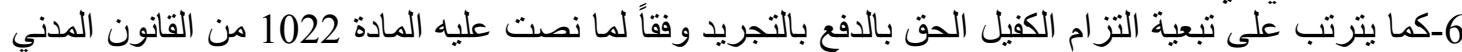

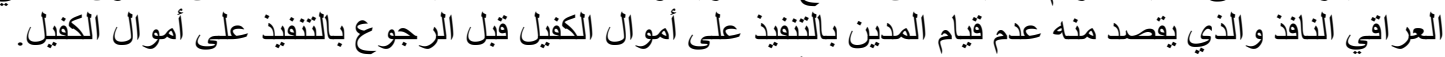

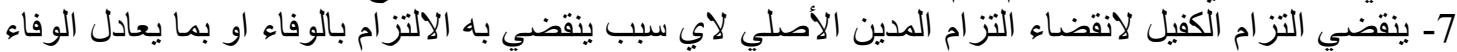

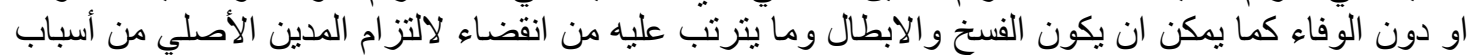

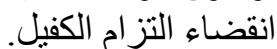

ثانياً : التوصيات

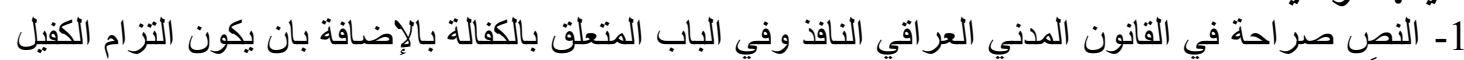

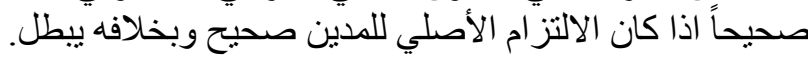


2- النص صراحة في القانون المدني العراقي فيما يتعلق بالكفالة على انه يلحق بالتزام الكفيل من اوصاف موجودة في التز ام المدين الأصلي.

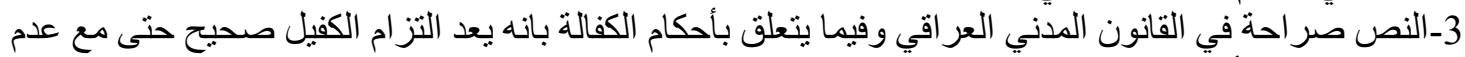

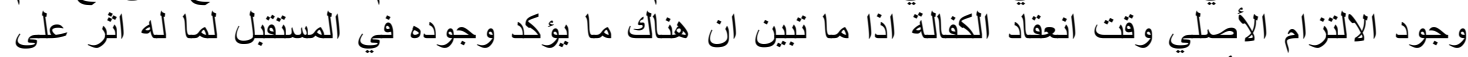

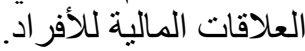
4ـالنص صرأحة في القانون المدني العر اقي النافذ وفيما يتعلق باحكام الكفالة على ان يكون دين الكفيل موازياً

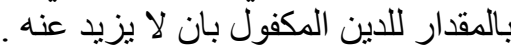

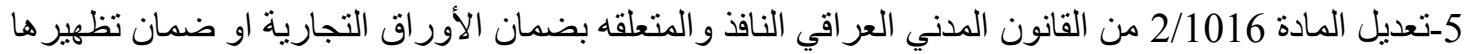

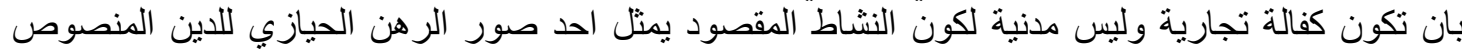
عليها في القانون المدني العر اقي النافذ وليس كفالة.

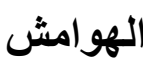

(1) د. عبد الرزاق احمد السنهوري، الوسيط في شرح القانون المدني ، دار احياء التراث العربي ، ج10 ، بيروت ، دون

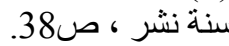
(2) د. عبد الفتاح عبد الباقي ، احكام القانون المدني المصري ـ التامينات الثخصية والعينية ، مطبعة دار نشر الثقافة ، ط2

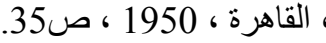

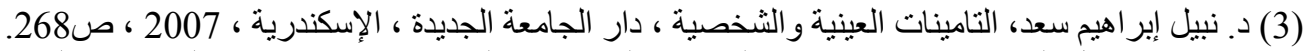

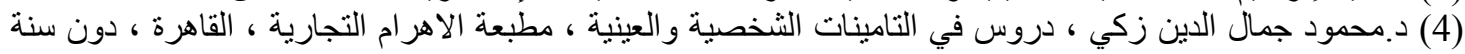

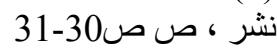
(5) د. يحيى عبد الودود ، عقد الكفالة ، مطبعة مصطفى بابي الحلبي وأو لاده ، مصر ، 1961 ، 1960 ، ص13.

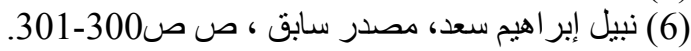

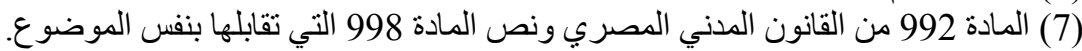

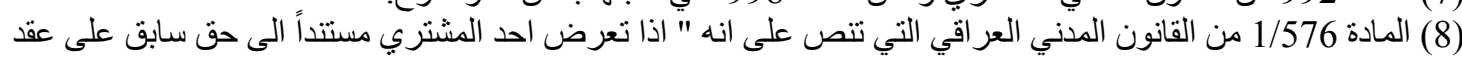

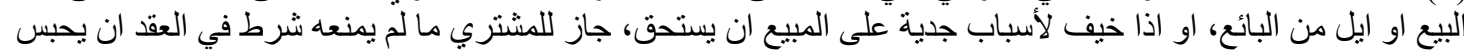

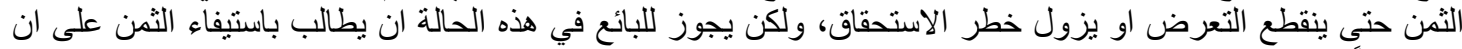

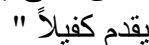
(9) د.سليمان مرقس ، الو افي في شرح القانون المدني ، معهد البحوث و الدراسات العريية ، ج3 ، الدجلد الثالث ، عقد

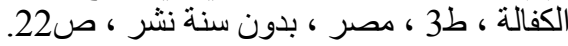
(10) د.نوفيق حسن فرج ، التامينات الثخصية و العينية - در اسة لعقد الكفالة و الرهن و الاختصاص و الامتياز ، مؤسسة

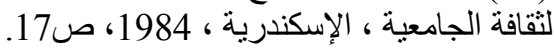
(11) د.منصور مصطفى منصور، عقد الإندائ، الكفالة ، المطبعة العالمية ، ط1 ، القاهرة ، 1960، ص30. د. عبد الرزاق احمد

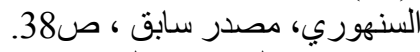

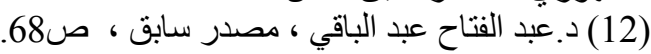

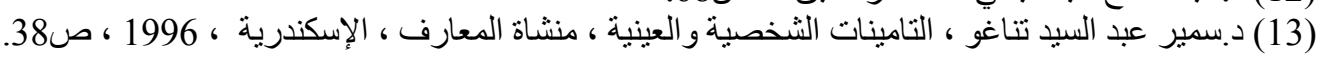

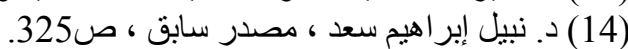

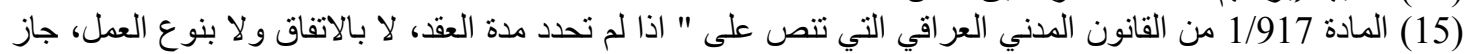

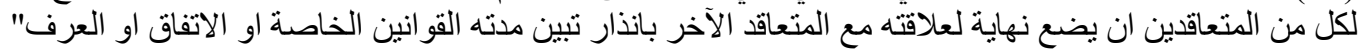

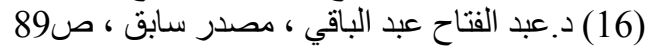

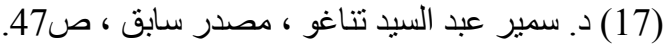

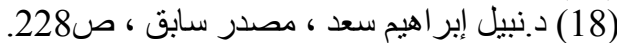

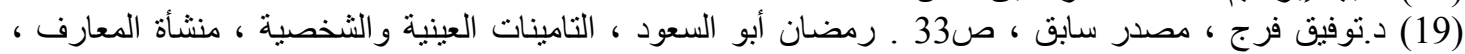

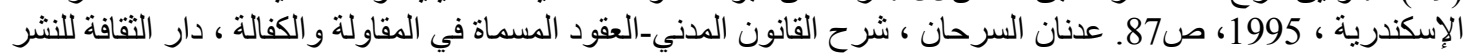

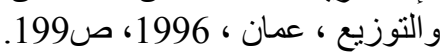
(20) د.نبيل إبر اهيم سعد ، احكام الالتز ام ، مصر ، دار ، دار المعرفة الجامعية ، 2000 ، ص19.

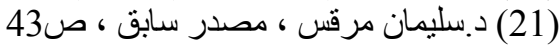
(22) (21) د.سمير عبد السيد تتاغو ، مصدر سابق ، ص40. 
(23) أنظر بهذا الصدد قرار محكمة استئناف بغداد التي اعتبرت فيه ان الكفيل غير ملزم الا في الحدود التي تم الاتفاق

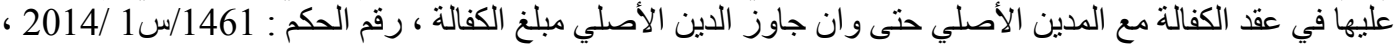

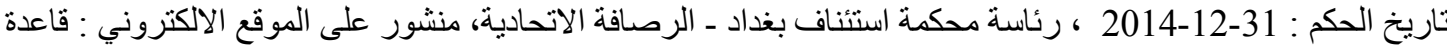

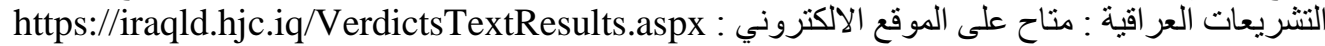

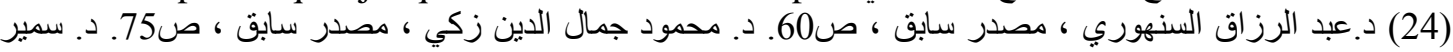

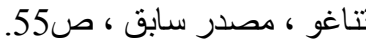

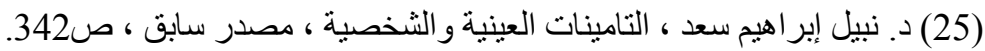

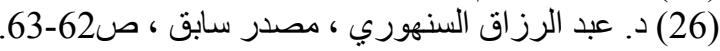

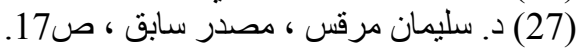

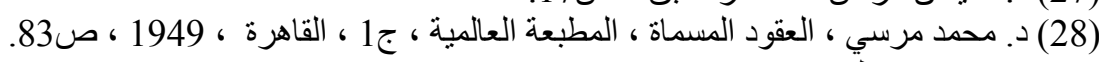

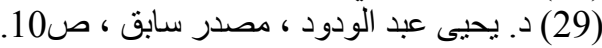

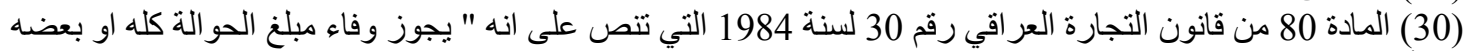

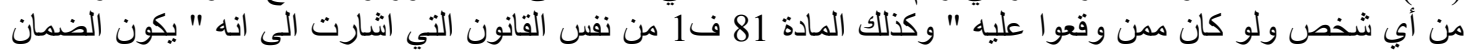

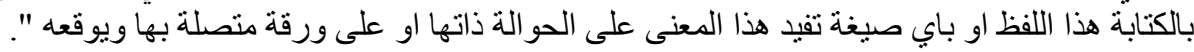

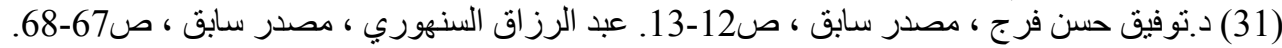

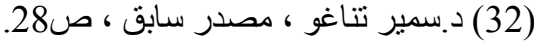

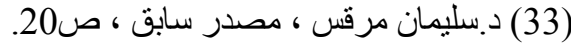

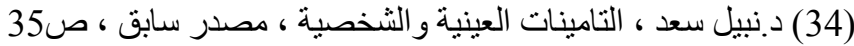

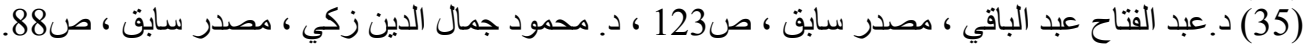

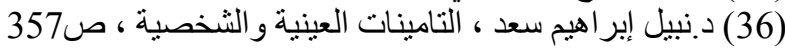

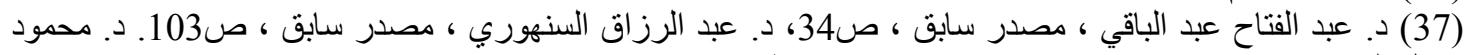

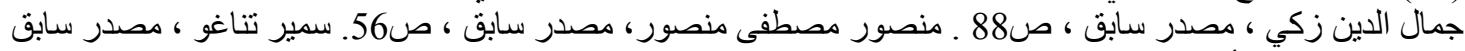

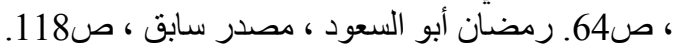

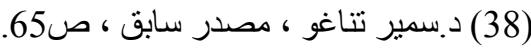

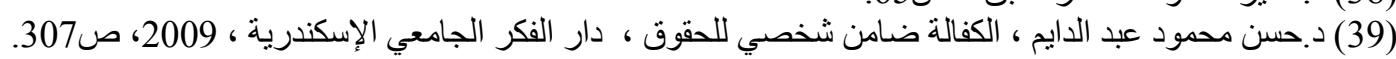

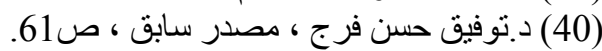

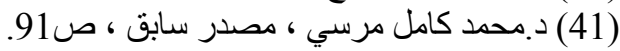

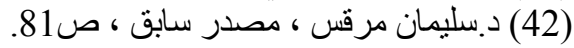

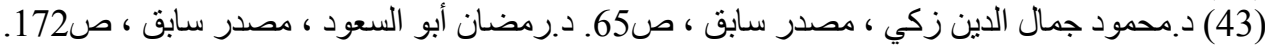

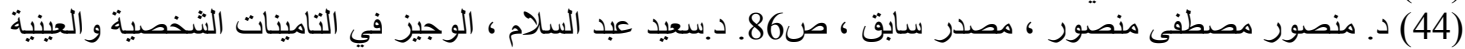

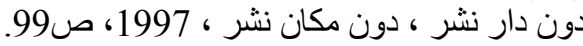

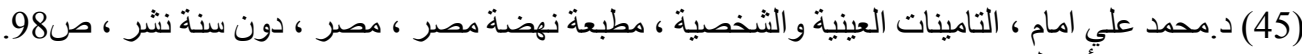

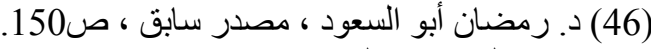

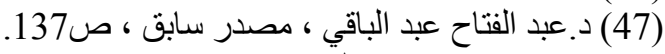

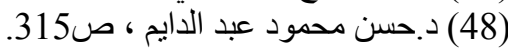

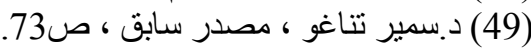

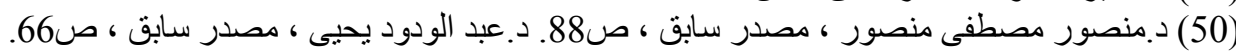

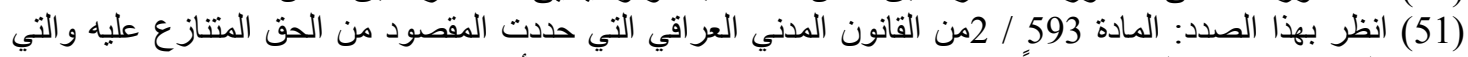

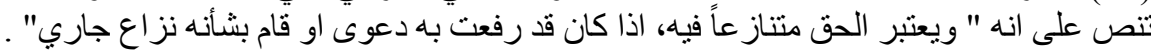

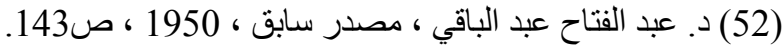

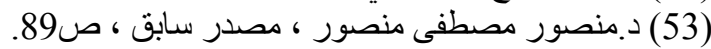

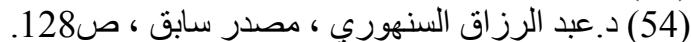

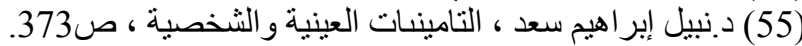

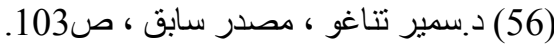

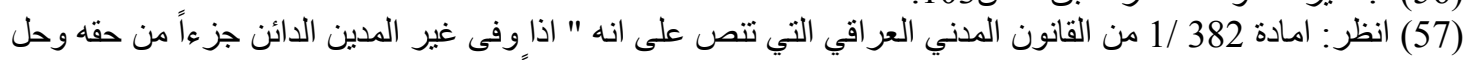

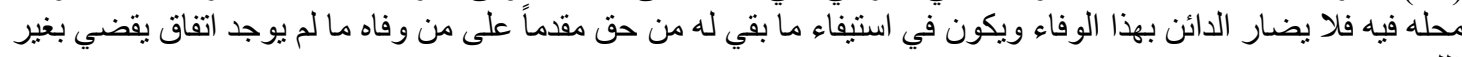




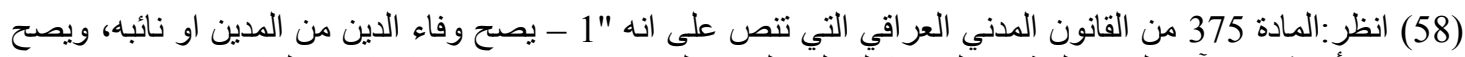

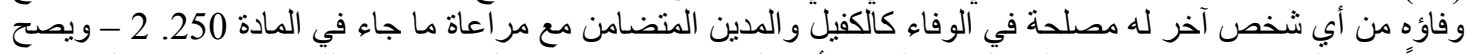

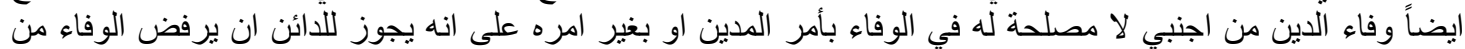

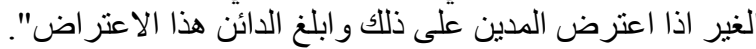
(59) انظر : المادة 365 من القانون الددني العر اقي " ينتقل الحق الى الى المحال له بصفئه وضماناته كالكفالة و الامتياز و الرهن

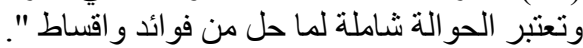

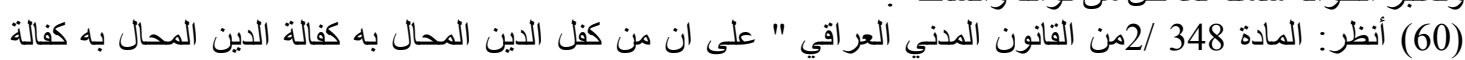

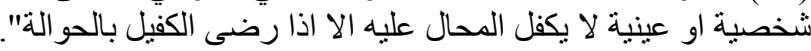

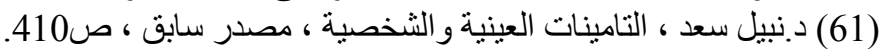
(62) أنظر : المادة 1/386 من القانون المديلئي العر اقي التي تنص على انه " - يقوم الايداع مقام الوفاء اذا قبله الدائن او

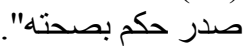

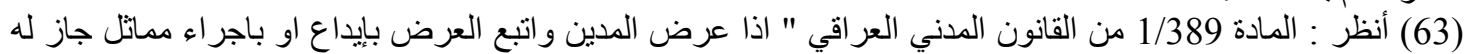

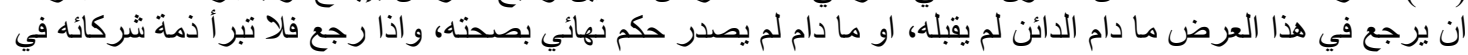

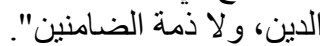

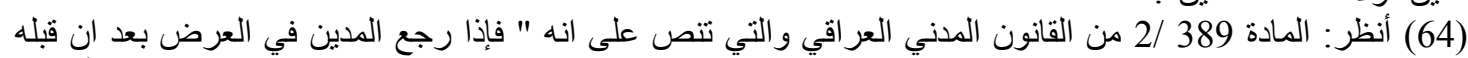

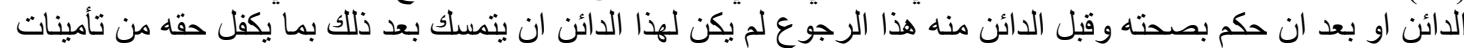

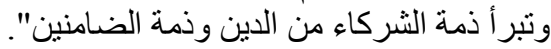

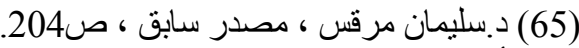

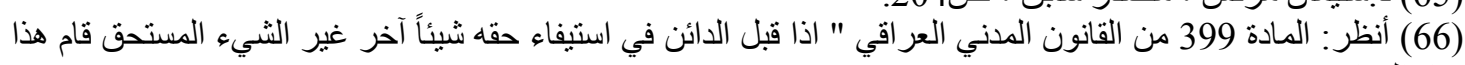

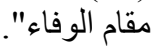

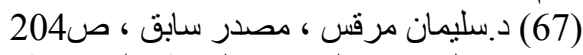

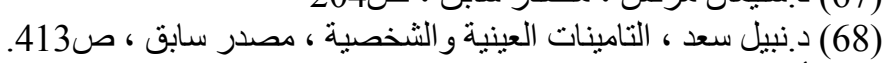

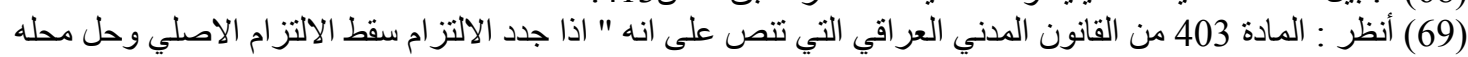

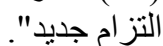

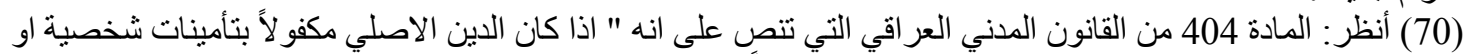

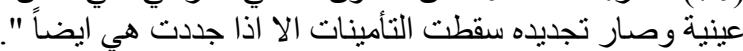

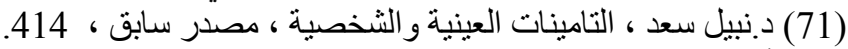

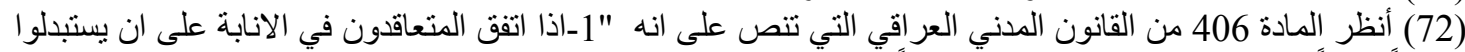

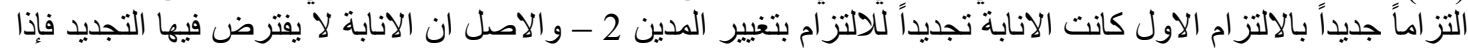

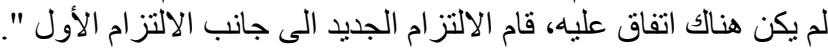

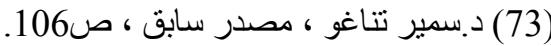
(74) أنظر: المادة 408 من القانون ، القانون المدني العر اقي التي تتص على انه " المقاصة، هي اسقاط دين مطلوب لثخص من

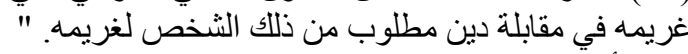
(75) أنظر المادة 413 من القانون المدني العر اقي التي تنص فلص على انه " تقع المقاصة بقدر الاقل من الدينين، و لا تقع الا اذا

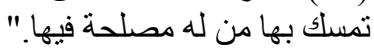

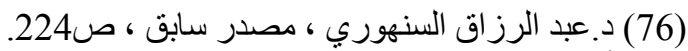

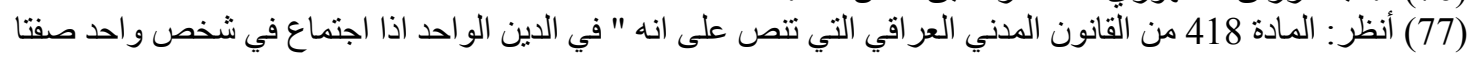

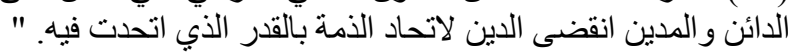

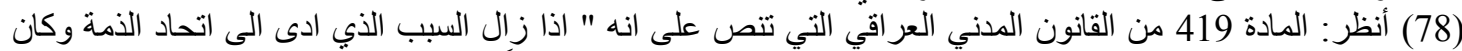

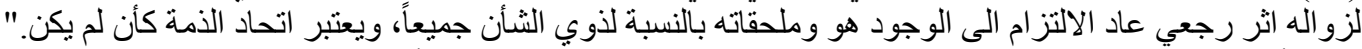

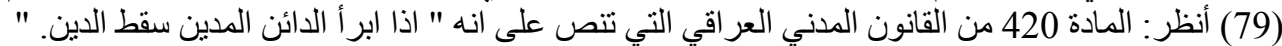

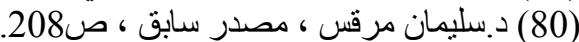
(81) أنظر: المادة 425 من القانون المدني العر اقي التي تنص على انه " ينقضي الالتزام اذا اثبت الددين ان الوفاء به

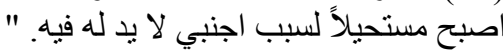

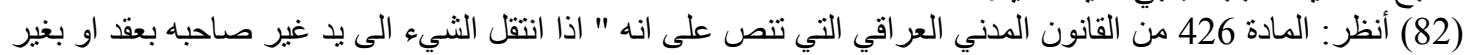

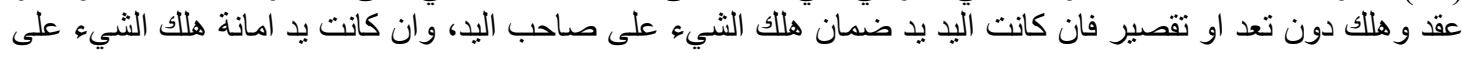


(83) د.منصور مصطفى منصور ، مصدر سابق ، ص72 ، ـ ـ عبد الفتاح عبد الباقي ، مصدر سابق ، ص226.

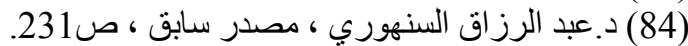

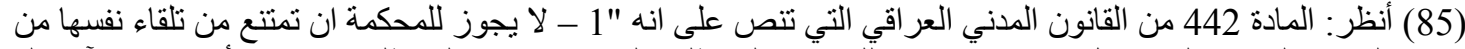

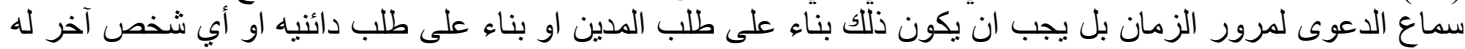

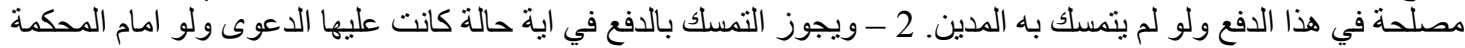

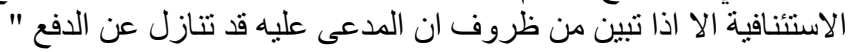

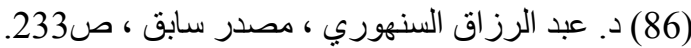

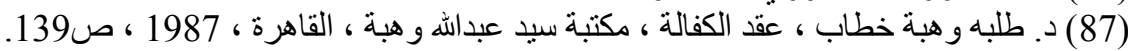

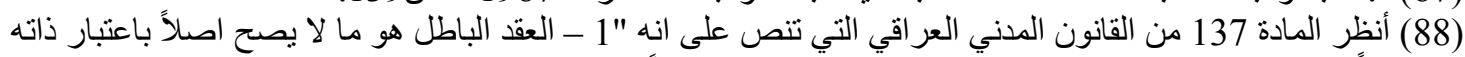

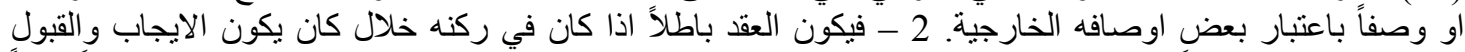

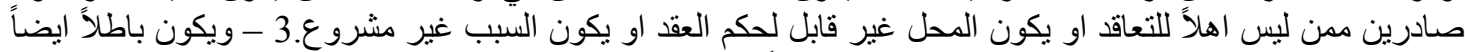

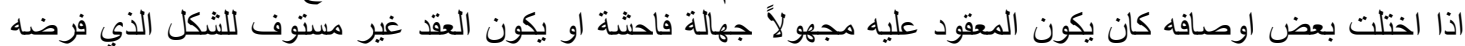

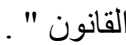
(89) (أنظر : المادة 2/138 من القانون المدني العراقي

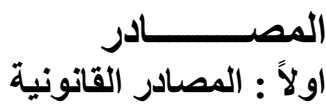

1-نوفيق حسن فرج ، التامينات الثخصية و العينية - دراسة لعقد الكفالة و الرهن و الاختصاص والامنياز ، مؤسسة الثقافة الجامعية ، الإسكندرية ، 1984 ، 198 ـ

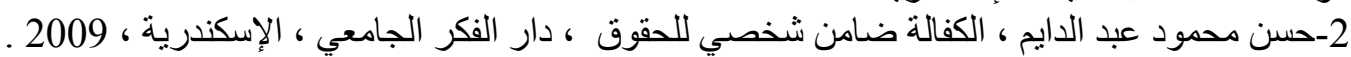

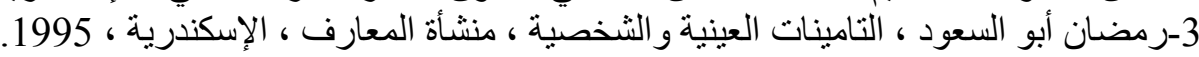

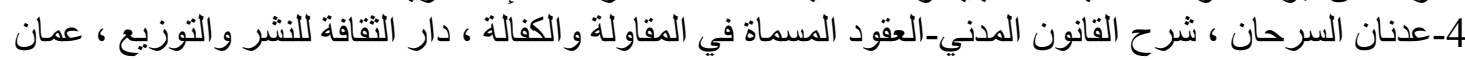
.1996 ،

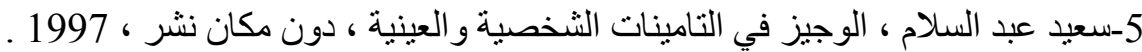

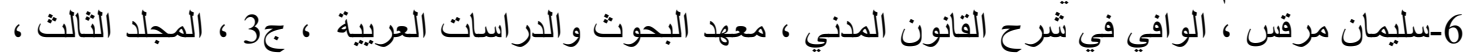

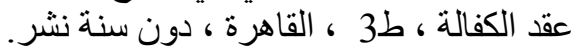

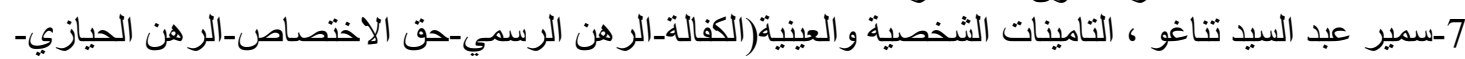
حقوق الامتياز)، منشاة المعارف ، الإن ، الإسكندرية ، 1996.

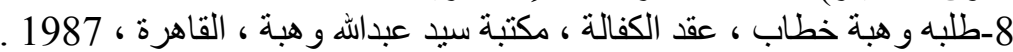

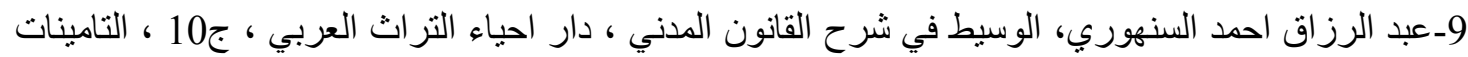

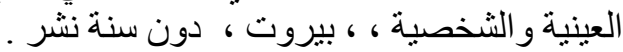

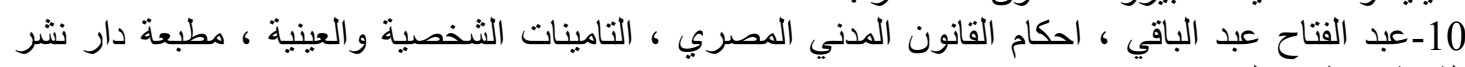

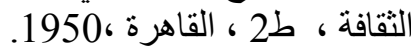

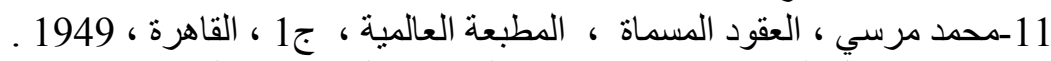
12-محمود جمال الدين زكي ، دروس في التامينات الثخصية و العينية ، مطبعة الاهر ام التجارية ، القاهرة ، دون سنة نشر.

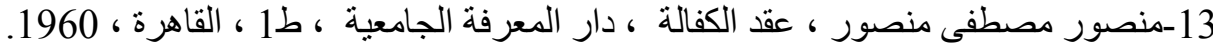

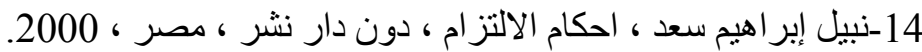

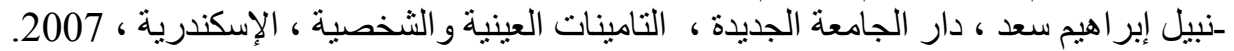

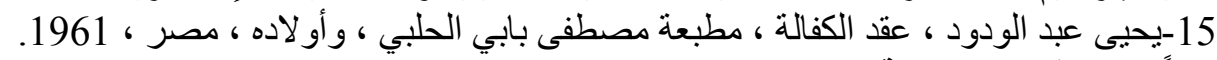
ثانياً : المواقع الاككترونية

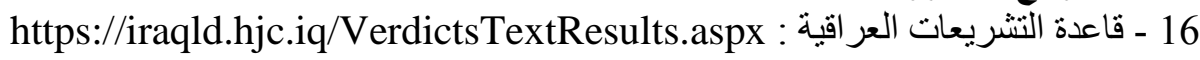


العدد (23)

Volume (23) August 2021

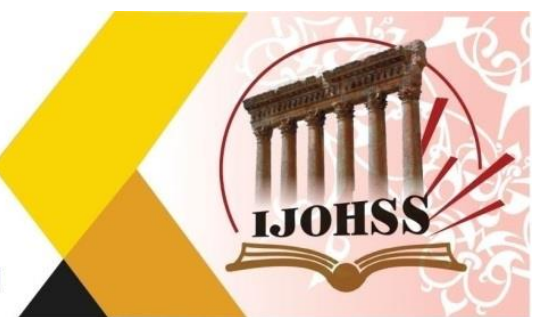

$$
\begin{aligned}
& \text { تالثاً : القوانين } \\
& \text { 17- القانون المدني العراقي رقم } 41 \text { لسنة } 1950 .
\end{aligned}
$$

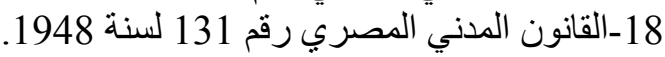

$$
\begin{aligned}
& \text { 19 قانون التجارة العر اقي رقم } 30 \text { لسنة } 1984 .
\end{aligned}
$$

\section{References}

\section{First, the legal sources}

1-Abd al-Razzaq Ahmad al-Sanhouri, Mediator in Explanation of Civil Law, House of Reviving Arab Heritage, C10, In-kind and personal insurances, Beirut, without .publication year

2-Abdel-Fattah Abdel-Baqi, Provisions of the Egyptian Civil Code, personal and in.kind insurances, Al-Thaqafa Publishing House, 2nd Edition, Cairo, 1950

3-Adnan Al-Sarhan, Explanation of the Civil Law - Contracts Named in Contracting .and Guarantee, House of Culture for Publishing and Distribution, Amman, 1996

4-Hassan Mahmoud Abdel-Dayem, Kafala as a Personal Guarantor of Rights, Dar AlFikr Al-Jamiah, Alexandria, 2009

5-Mahmoud Gamal El-Din Zaki, Lessons in Personal and In-Kind Insurance, Al.Ahram Commercial Press, Cairo, without publication year

6-Mansour Mustafa Mansour, the sponsorship contract, University Knowledge House, .1st floor, Cairo, 1960

7-Muhammad Morsi, The Named Contracts, International Press, Volume 1, Cairo, .1949

8-Nabil Ibrahim Saad, New University House, In-kind and Personal Insurance, .Alexandria, 2007

9-Nabil Ibrahim Saad, Provisions of Commitment, without a publishing house, Egypt, .2000

10-Ramadan Abu Al-Saud, In-kind and Personal Insurance, Mansha'at Al-Maaref, .Alexandria, 1995

11-Saeed Abdel Salam, Al-Wajeez in personal and in-kind insurances, without a place .of publication, 1997

12-Samir Abdel-Sayed Tanago, personal and in-kind insurances (guarantee - official mortgage - right of jurisdiction - possession mortgage - franchise rights), knowledge .facility, Alexandria, 1996

13-Suleiman Marks, Al-Wafi fi Sharh Civil Law, Institute of Arab Research and Studies, Volume 3, Volume Three, Sponsorship Contract, 3rd Edition, Cairo, without .publication year

14-Talaba Wahba Khattab, The Guarantee Contract, Sayed Abdullah Wahba Library, .Cairo, 1987

15-Tawfiq Hassan Farag, Personal and In-Kind Insurances - A Study of the Guarantee Contract, Mortgage, Specialization and Excellence, University Culture Foundation, .Alexandria, 1984

16-Yahya Abdel-Wadoud, The Bail Contract, Mustafa Babi Al-Halabi Press, and his .sons, Egypt, 1961 


\section{المجلة الدولية اللهلور اللأسانية والإمتماعية}

International Journal on Humanities and Social Sciences website:www.ijohss.com Email:editor@ijohss.com ISSN: 2415 - 4822

Second, the websites

17-Iraqi Legislation Base: https://iraqld.hjc.iq/VerdictsTextResults.aspx

Third: the laws

18-Iraqi Civil Code No. 41 of 1950

19-Egyptian Civil Code No. 131 of 1948

20-Iraqi Trade Law No. 30 of 1984 